\title{
The Processional Oct. Lat. 794 of the Budapest National Széchényi Library. A Re-identification
}

\author{
Gabriella GILÁNYI \\ Institute of Musicology \\ Research Centre for the Humanities \\ Hungarian Academy of Sciences \\ Táncsics Mihály u. 7, H-1014 Budapest, Hungary \\ E-mail: gilanyi.gabriella@btk.mta.hu
}

(Received: February 2015; accepted: April 2015)

\begin{abstract}
The Budapest National Széchényi Library keeps a Pauline manuscript compiled in 1644. Based on a possessor's entry at its very beginning, the source Cod. Lat. 794 has so far been referred to in the literature as the Pauline Processional of Ujhely but its content has never been thoroughly investigated. The original aim of this study was to fill this gap by carrying out a codicological, liturgical and musical survey and, finally, producing a full description and detailed evaluation of the manuscript. However, the many-sided analysis has eventually led to unexpected findings, which make the earlier consensus about the provenance of the book questionable. First of all, while the manuscript uses the typical Pauline notation, its style and ductus differ markedly from the notation of the 1623 Gradual belonging definitely to the monastery of (Sátoralja)újhely, whereas it shows striking similarities to $17^{\text {th }}-18^{\text {th }}$-century manuscripts of the Croatian Paulines. Other characteristics such as the sequence and designation of the stations in the processional topography and the last unit of the book, which is a notated Passional in Croatian language, point toward Lepoglava, the centre of the Pauline province as the possible provenance. A comparative analysis of the melodies also support this hypothesis.
\end{abstract}

Keywords: Pauline Processional, Sátoraljaújhely, post-Tridentine chant, Lepoglava

\section{Introduction}

Unexpected insights can suddenly change the objective of a scholarly investigation relegating the original aim of study to a secondary place. This happened to me during the examination of a notated manuscript that is widely known, survives intactly, is available at its repository, and has earlier been registered in literature 
with a byname referring to its alleged place of origin. The manuscript Oct. Lat. 794 held at the collection of the Budapest National Széchényi Library is dated 1644 and called Pauline Processional of Újhely in the shop language of Hungarian chant research. ${ }^{1}$ The naming reflects the self-definition of the Processional that seems to be unambiguous. Albeit the title-page is missing, the possessor's entry in cursive handwriting at the beginning of the book hints at the place and community of its use: an apparently authentic contemporaneous inscription in ink on the recto of folio 1 names the Pauline convent of Újhely - i.e. Sátoraljaújhely, a town in the historical Zemplén County in northern Hungary, since 1920 on the Hungarian side of the border to Czechoslovakia (now Slovakia, see the map in Appendix 1) - as its owner (Plate 1). ${ }^{2}$ In the body of knowledge on Hungarian chant collected to date conspicuously little relevant information on the volume can be found. The reason for the lack of interest lies presumably in the year 1644 indicated in the possessor's entry. ${ }^{3}$ It was probably due to the late date of its compilation, which is confirmed by the examination of its appearance and contents that the Processional was omitted from Hungarian source catalogues, bibliographies and monographs as these focused for the greater part on listing and exploring the medieval liturgical manuscripts from before $1526 .{ }^{4}$

Of course the Processional was registered by Janka Szendrei, who entered it in her catalogue of notated manuscripts from medieval Hungary under C 107 with the following fundamental data:

\section{UJHELYI PÁLOS PROCESSIONALE [PAULINE PROCESSION-} AL OF ÚJHELY] - 1644 - OSzK Oct. Lat.794 - 143 fol - Processional chants, a Tonary, funeral, selected Vespers antiphons and hymns, the Te Deum, invitatories, lamentation, suffrages, a Passion in Slovak - with Hungarian notation - Hungarian, for the Pauline monks of Újhely. ${ }^{5}$

1. In RISM: H-Bn Cod. lat. 794.

2. Hungarian entry in blue ink: 1644. év / Újhelyi pálos kolostor, hiányos [1644 / Pauline monastery of Újhely, defective]; a Latin entry in black ink reads: Conventus Ujhélyensis O.S.P.P.E.

3. The explicit on folio $110 \mathrm{v}$ of the source corroborates this date.

4. It is missing from the catalogue of Polikarp Radó, Libri liturgici manuscripti bibliothecarum Hungariae et limitropharum regionum (Budapest: Akadémiai Kiadó, 1973) and from the work by Csaba Csapodi - Klára Csapodiné Gárdonyi, Bibliotheca Hungarica. Kódexek és nyomtatott könyvek Magyarországon 1526 elött I-III. [Bibliotheca Hungarica. Codices and printed books in Hungary before 1526 I-III] (Budapest: Magyar Tudományos Akadémia Könyvtára, 1988, 1993, 1994) (=A Magyar Tudományos Akadémia Könyvtárának Közleményei 23/98, 31/106, 33/108). It is used neither in CAO-ECE nor the GRADUALIA project (http://hunchant.eu/cao-ece, http://hunchant.eu/gradualia). The source is also left unmentioned in the catalogue of Béla Stoll, A magyar kéziratos énekeskönyvek és versgyüjtemények bibliográfiája 1542-1840 [Bibliography of Hungarian manuscript chantbooks and verse collections 1542-1840] (Budapest: Balassi Kiadó, 2002).

5. Janka Szendrei, A magyar középkor hangjegyes forrásai [Notated manuscripts from medieval Hungary] (Budapest: Institute for Musicology of the Hungarian Academy of Sciences, 1981) (= Mühelytanulmányok a magyar zenetörténethez 1), 70. 
Plate 1 Processional Oct. Lat. 794, Budapest National Széchényi Library, f. 3r

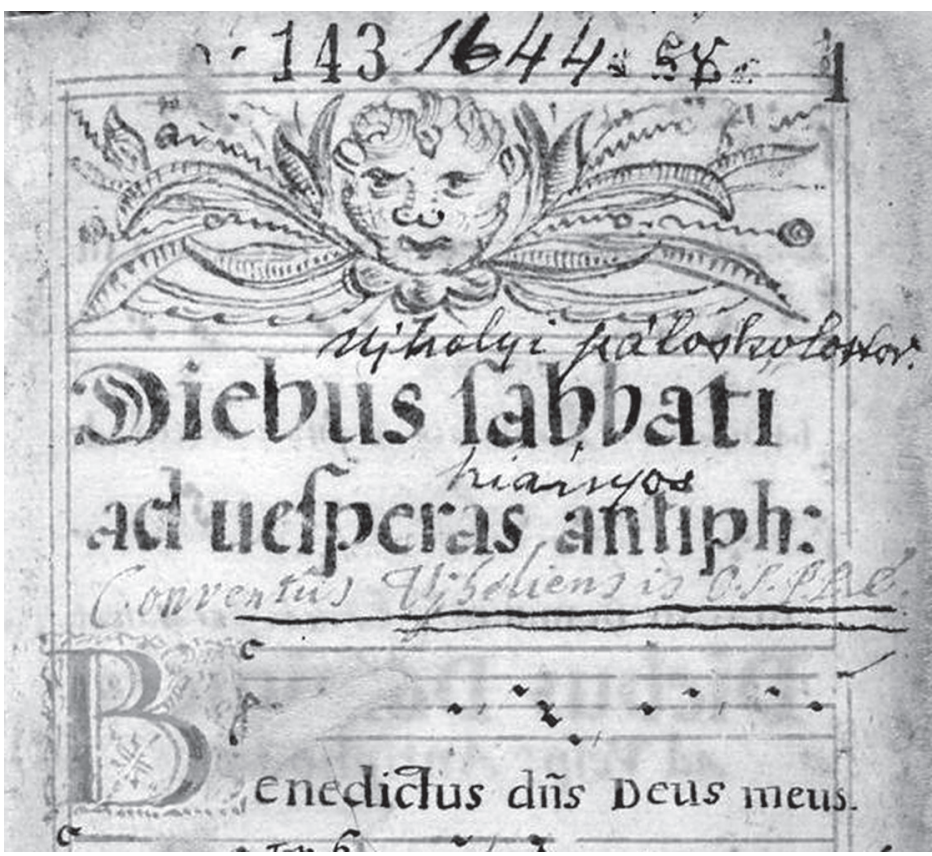

Apart from this succinct enumeration of data, Szendrei only dwelt on the Processional in passing. When commenting on the single items in the catalogue's introduction, she mentioned it as one of the late sources of the Gregorian chant repertory in Hungary that deserve scholarly interest. ${ }^{6}$ Szendrei also enumerated the Processional among the retrospective sources of the Hungarian Pauline notation in the first volume of Magyarország zenetörténete [The Music History of Hungary]. ${ }^{7}$ However, the manuscript has neither been fully treated by Szendrei nor has anybody undertaken a more profound analysis later.

The procrastination of scholarly treatment is all the more regrettable as a first survey already evidences the uniqueness of this collection of chants. Since no notated medieval Processional or Gradual from the use of the Hungarian-founded Order of St. Paul the First Hermit survive, the examination of any document of relevant contents opens up new vistas for the research of the Pauline liturgy in general. Experience shows that this observation holds also true for such particular

7. Janka Szendrei, "Retrospektív források a 16-17. századból" [Retrospective sources from the $16^{\text {th }}-17^{\text {th }}$ centuries], in Magyarország zenetörténete I, Középkor [Music history of Hungary, vol. I, Middle Ages] ed. Benjamin Rajeczky (Budapest: Akadémiai Kiadó, 1988), 44, note 182. 
cases when the content of the source is not medieval per se but reflects - as in this instance - the state of liturgical music after the reform of the Council of Trent.

In recognition of this I have in recent years devoted several studies to the reconstruction of the late (post-Council) Pauline music tradition, analyzing the specific features of its retrospective repertory, melodic style and notation. ${ }^{8}$ My investigations have borne out that the Order of St. Paul belonged to the most conservative church communities after the Council of Trent in Europe. The introduction of the liturgical reforms in the Order of St. Paul after 1600 did not mean abandoning the medieval musical tradition as it was generally the case in the Hungarian church. By adapting the old melodies to the new Roman rite, the Paulines created specific liturgical forms that remained valid in the everyday practice until the dissolution of the order. The Paulines adopted the new liturgy early, some 30 years before the church reform in Hungary. ${ }^{9}$ This lead gave the Order of St. Paul an opportunity to carry out the transformation process carefully and circumspectly, and to find a convincing solution to the excruciating problems of liturgical chant. ${ }^{10}$ For the unity of liturgy and music that had practically been unimpaired from time immemorial has now been broken. Rome did not issue a central decree on the chant during the $17^{\text {th }}$-century liturgical reform and did not specify what kind of melodies should be linked with the new liturgical order and the completely reshaped and shortened texts in the daily church music practice. The Pauline Order closed the gap in the musical interpretation of the new liturgy very creatively by adapting, wherever possible, the texts of the new rite to the melodies of the old one. ${ }^{11}$ As a result, the melodic material of the late sources allows the study of a specifically

8. See Gabriella Gilányi, "Zenei archaizmusok és neologizmusok a 18. századi pálos zsolozsmában” [Musical archaisms and neologisms in the $18^{\text {th }}$-century Pauline Office], in Zenetudományi Dolgozatok 2009, ed. Gábor Kiss (Budapest: Institute for Musicology of the Hungarian Academy of Sciences, 2010), 69-96; eadem, "Retrospective or not? Pauline Introits in the $18^{\text {th }}$-century Hungary," in Der Paulinerorden: Geschichte, Geist, Kultur, ed. Gábor Sarbak (Budapest: Szent István Társulat, 2010), 503-510; eadem, "Horvát variáns, magyar variáns? 18. századi pálos dallamaink új források fényében" [Croatian variants, Hungarian variants? $18^{\text {th }}$-century Pauline melodies in the light of new sources], in Hagyomány és megújulás a liturgiában [Tradition and renewal in the liturgy], ed. Andrea Kovács (Budapest: Liszt Ferenc Academy of Music - Hungarian Church Music Society, 2012), 159-170; eadem, "A hiányzó láncszem? Egy 1687-es pálos antifonále Crikvenicából" [The missing link? A Pauline Antiphoner of 1687 from Crikvenica], Magyar Zene 52/1 (2014), 5-15.

9. The reformed Roman rite was officially introduced to Hungary at the national synod of Nagyszombat (now Trnava, Slovakia), later seat of the archbishopric in 1630, during the reign of Cardinal Péter Pázmány, archbishop of Esztergom and prince-primate of Hungary. See Nándor Knauz, “A magyar egyház régi szokásai I. A római rítus behozatala" [The old traditions of the Hungarian Church I. Introduction of the Roman rite], Magyar Sion 3/6 (1865), 401-413.

10. See Emil Kisbán, A magyar Pálosrend története [The history of the Hungarian Order of St. Paul] (Budapest: Pálos kolostor, 1940), vol. II, 201; Janka Szendrei, "Latin nyelvű gregorián ének" [Latin Gregorian chants], in Magyarország zenetörténete II, 1541-1686 [Music History of Hungary, vol. II, 1541-1686], ed. Kornél Bárdos (Budapest: Akadémiai Kiadó, 1990), 158; eadem, "Der Ritus Tridentinus und die Paulanische Tradition im Ungarn des 17. Jahrhunderts: Kompromiß, Kontrafaktur, Modifikation," in The Past in the Present. Papers read at the IMS Intercongressional Symposium and the 10th meeting of the Cantus Planus, ed. László Dobszay (Budapest: Institute for Musicology of the Hungarian Academy of Sciences, 2003), 330.

11. By contrast, in the liturgical plainchant practice of the Hungarian church the large 'unofficial' cantus romanus versions gained ground spreading through editions printed mostly in Venice. 
archaic liturgical music style that directly reflects the medieval Pauline melodies even if with the progress of time the musical details more and more strongly deviated from the old Gregorian melodies.

Studying the post-1600 retrospective liturgical music of the Paulines can be particularly informative for the more peripheral liturgical services outside the Mass and the Office that could be and were, in fact, less centrally regulated and locally more important. These ceremonies were in all probability transformed to a lesser extent after the Council of Trent; consequently they remained more archaic and preserved the medieval elements in a purer state. The processions, which have remained - due to lack of medieval sources - unexplored in the context of the liturgical traditions of the Order of St. Paul so far, can be included in this group. ${ }^{12}$

For this reason I decided to take a closer look at the Újhely Processional more or less neglected before. However, I realized that I had to temporarily disregard the task of evaluating the internal and external characteristics of the volume for the purpose of the reconstruction of the post-Tridentine version of the Pauline processional when during the process of source description serious doubts emerged concerning the assumed origin of the Processional. With the progress of investigation, these doubts gained more and more ground and gave the analysis a new direction. The essential issue to concentrate on became whether the source could indeed be brought into close relation with Sátoraljaújhely or if this provenance could be indisputably refuted, establishing the actual place of origin by means of data gathered from the book itself.

In the following I am going to sum up the individual characteristics of the source, which I have cleared in the process of its codicological, church historical, liturgical and musical analysis, and which throw a fresh light on the history of the manuscript - including the generally accepted predicate "of Újhely" in its byname.

\section{Outward appearance and notation}

The Processional consisting of 143 paper folios is a small-sized source of modest appearance and workmanship showing the limited capabilities of $17^{\text {th }}$-century Hungarian bookmaking. Its format resembles medieval pocket-books for private use which were easy to hold in one hand and turn the pages over. However, chances are slim that the Processional belonged only to one person instead of the whole community, since the notated liturgical books were scarce and precious in those days and served the purpose of maintaining the tradition. ${ }^{13}$

12. They probably preserved the musical tradition of Esztergom similar to the other types of liturgical ceremonies (Mass, Divine Office).

13. Private property cannot be entirely excluded, either. An argument in favour of the private use can be the list of names of Pauline monks entered in blurred script in pencil at the end of the book. It is also conceiv- 
The Processional has seven unusually short staves on each page. Compared to the small size, it is a carefully, minutely elaborated piece of work and this meticulous care holds generally true for the presentation of the content as well. In agreement with tradition, the scribe used several colours: red, black, and green ink. Green served primarily for setting off figural-ornamental elements ${ }^{14}$ and entering the captions of the most important feasts respectively. The inscriptions of minor rank and the rubrics are in red; the capital letters at the beginning of the items, which are scarcely ornamented, appear for the greater part in red and black. Neither the text nor the musical notation bear witness to a professional scribe; they rather suggest the hand of a musically trained Pauline monk. It was by no means uncommon at the time of the decline of the medieval book culture that the notated books were no more made by professional musical scribes (and professional workshops supporting them) but copied by the choirmaster to meet the needs for liturgical music of the monastery.

In the main text two kinds of textualis can be distinguished. The initial words of the musical items imitate the standard, printed text writing and are then followed from a random point onward by the text in cursive handwriting. In the musical notation of the Processional the full heritage of the Pauline notational tradition can be observed. The source preserves the medieval Hungarian musical notation in a cursive form unsuitable for keeping the exact proportion of the various elements of the neumes; the fast tempo of writing renders the shaping of the elements and their standardized linking difficult. The cursive notation of the book shows peculiarities which point beyond the writer's individual style and characterize in general the Pauline notation. Here belong the climacus, which begins with double points as well as the shape of the scandicus departing from the conjunct Hungarian form and disintegrating into its single elements. The way the medieval Hungarian neumes fragmented into their elements in the $16^{\text {th }}$ century was very special indeed, and the $17^{\text {th }}$-century half cursive notation of the Processional provides a late example for it (see Table 1, column 1). In the drawing of the pes, torculus, and scandicus the complete separation of the notes and their joining lines can be observed. This happens very spectacularly in the case of a scandicus progressing in seconds: it is clearly visible that the neume is constructed of five(!) separate strokes of pen of which the second and third, and the fourth and fifth ones run into each other in a certain part of the neumes.

It is characteristic of the Gothicized style of writing that the linking lines of notes/note groups grow thin in most signs while the elements marking the notes

able that the choirmasters responsible for the volume are listed there and not the owners.

14. The drawn figures are as follows: head entwined with foliation and leaves (f. 1r), flower motif with leaves around it to conclude a section of the book (following the processions, before the Passional) (f. 88r), palmette concluding the Processional (f. 110v), large-sized pen-and-ink drawing with flowers and foliation at the end of the St. Matthew Passion (f. 136r). After the index a bunch of flowers. 
themselves get slightly enlarged and assume irregular rhombic shapes in the cursive script. ${ }^{15}$ In this respect the Processional lags behind its own time and agrees with the medieval Pauline notation: the attenuation of the linking lines can only be observed in certain neumes, e.g. the clivis and occasionally the pes. Some signs (clivis, conjunct climacus) still bear traces of the medieval flexibility of neumes, drawn with one momentum, instead of the fragmented way of writing. For example, the traditional shape of the clivis only changes in respect of the intense marking of the head of notes compared to the medieval way of writing. Later, in $18^{\text {th }}$-century Pauline notation, the clivis is stylized to a shape reminiscent of $z$ (see clivis signs Table 1), which is foreshadowed by the formation of the clivis in the present source.

In sum, the writing as a whole shows a condition of the writing manner which is characteristic of the $16^{\text {th }}-17^{\text {th }}$-century sources of liturgical music in general, namely, that after the medieval prosperity the traditional Hungarian notation started to loosen and get transformed to shorthand. One can hardly expect to see a work of professional quality without strong financial and institutional background. This was sadly missing since the Ottoman wars and occupation have destroyed practically the entire network of medieval church institutions cultivating plainchant in Hungary. ${ }^{16}$

It should be emphasized, though, that this writing is intensely traditional, so to say a return to the Middle Ages. It seems that this cursive/half cursive type of Hungarian notation remained the only way of writing in the weakened Hungarian church, more precisely in the institutions controlled by the Pauline Order after the Council of Trent where the notation of books (also) ensured the continuity between the new era and the medieval Hungarian tradition.

The examination of the "Processional of Újhely" had in due course to be extended to the comparison of its notation with the writing style of the Pauline Gradual of (Sátoralja)újhely written two decades earlier (Plate 2). ${ }^{17}$ The inspection raised exciting questions. It turned out that although both notations are half-cursive in character, the writing displays great differences concerning the ductus, the quality and the degree of stylization (see Table 1, columns 1 and 3). Janka Szendrei wrote about the notation of the Gradual of Újhely as follows:

The musical script ... is Hungarian notation, more specificly the Pauline version of the medieval Hungarian notation in a half-cursive form ... An evidence of the late date of compilation is the disjunct

15. Janka Szendrei, Középkori hangjegyírások Magyarországon [Medieval notations in Hungary], (Budapest: Institute for Musicology of the Hungarian Academy of Sciences, 1999) (= Mühelytanulmányok a magyar zenetörténethez 4), 64-66.

16. See Szendrei, A magyar középkor hangjegyes forrásai, 15.

17. See Graduale Romanum ad Usum monasterii de Újhely (1623), ed. Janka Szendrei (Budapest: Institute for Musicology of the Hungarian Academy of Sciences, 2010) (= Musicalia Danubiana 24). 
way of writing the neumes (uniformly shaped, separate note heads, thin connecting lines). ${ }^{18}$

This implies that we have here a half-cursive, standardized notation making a more professional impression and representing a higher quality than that of the Processional: ${ }^{19}$ its note-forms are more firmly and precisely drawn and, as a result, the shaping of the neume forms makes a more careful, uniform, and homogeneous effect. Thanks to the consistently differentiated use of thin and thick elements, the overall picture is well-ordered but also varied and dynamic, largely due to the bold treatment of pen plays. ${ }^{20}$ Further characteristics of the writing include concave-shaped rhomboid note heads, angular joining lines, zigzag series of notes and flash-like motives of the script. The descending points of the climacus are linearly lengthened for the sake of widening of the neumes and enlarging the size of the note heads. The characteristics of the musical notation of the Gradual are idiosyncratic to such a degree that it is impossible to deduce from them the manner of writing of the 1644 Processional. Although the difference between the two notations may arise from the music scribes' different educational background and can possibly be explained by the different type and function of the books - one of them prepared for humble use, the other perhaps serving representative purposes - one might also presume that the different musical notations of the Gradual and the Processional reflect the working method of two different Pauline notational workshops, each with its own medieval tradition: that of Sátoraljaújhely in the case of the Gradual and another unknown one for the Processional. The Pauline communities have spread over large territories in Central Europe. Outside of the Kingdom of Hungary several Croatian, Polish and German monastery foundations are known. ${ }^{21}$ This taken into account, one could easily surmise that the Processional's place of origin lies geographically far away from Újhely.

Following this train of thought, I extended the paleographic analysis over more remote monasteries of the Pauline Order and included $18^{\text {th }}$-century retrospective sources as well because manuscripts from the $17^{\text {th }}$ century are small in number. ${ }^{22}$ The archaizing musical notation of the Processional reminiscent of late $16^{\text {th }}$-century cursive scripts directed my attention towards the strongly tradition-

18. Ibid., 10.

19. The slender linking lines represent a post-medieval peculiarity of the Hungarian Pauline notation which is, as seen above, as yet by no means a homogeneous principle in the notation of Professional written 21 years later. This means that the chronologically later script of the Processional is strongly archaizing compared to the explicitly modern make-up of the Gradual.

20. Hence the conspicuous entry strokes, e.g. the $z$-shaped points that meet at the double head of the climacus.

21. See Kisbán, A magyar Pálosrend története, vol. I, 326-331.

22. Only a Gradual from 1687 can be safely taken into consideration. Ms. mus. 7240 in the Music Collection of the National Széchényi Library is in all probability a source of Pauline origin but the verification of it needs further studies. See Szendrei, A magyar középkor hangjegyes forrásai, C 124; Gábor Kiss, "Tridentinum előtt és után. A magyarországi pálosok ordinárium-hagyománya” [Before and after the Council of Trent. 
Plate 2 Musical notation of the Processional (f. 86r) and Gradual of Újhely (f. 1r)
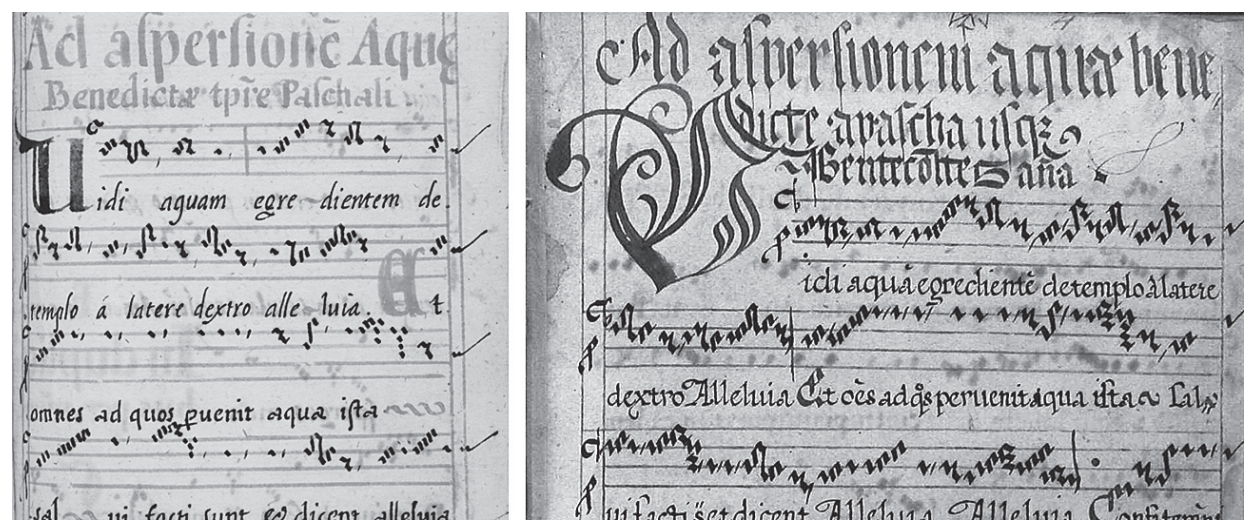

alist Croatian province, which in 1700 was separated from the Hungarian one. Its musical style has been considered to be much more archaic than the post-Tridentine melodic material of the Hungarian province and the presence of conservative elements in its notation to be more pronounced. It is enough to compare some $18^{\text {th }}$-century Hungarian and Croatian neumes to see clearly in which direction the Pauline musical notation progressed in the $17^{\text {th }}$ century (see Table 1). The Croatian script is less careful and unambiguously cursive as opposed to the Baroque notation of the Pauline Order in the Hungarian province. The Hungarian script which shows stylized, uniformly shaped rhomboid note heads and homogeneously thin linking lines throughout, appeared in representative paper codices during the $18^{\text {th }}$ century as an ornamental notation suitable for establishing a new, restylized form of writing. The appearance of the contemporary Croatian examples as well as their notation and script are more modest; similarity to Hungarian instances can only be observed in linking the notes to each other.

Manuscripts with Croatian Pauline musical notation have emerged from Lepoglava, Crikvenica, Csáktornya (Čakovec), and Olimje. ${ }^{23}$ Strong analogies both in the script as a whole and in particulars could only be found with the Lepoglavan codices (see Table 1, column 6). The writing variety of Lepoglava stands clearly apart from the rest: it is the least stylized, negligent notation retaining its cursive character well into the $18^{\text {th }}$ century, differentiating between the thin and thick elements less distinctly than the style of all other $18^{\text {th }}$-century Croatian musical manuscripts of the Paulines. While in certain signs the linking lines grow thinner

The ordinary tradition of the Hungarian Paulines], in Zenetudományi Dolgozatok 2009 (Budapest: Institute for Musicology of the Hungarian Academy of Sciences, 2009), 97-136, here: 106.

23. The most important sources from Croatian territories are: HR-Zu R 3612, HR-Zu R 3004, HR-Zu R 3038, HR-Zu MR 178, H-Bu A 116. See the full list of cited sources and the list of the abbreviations at the end of this study in Appendix 3. 


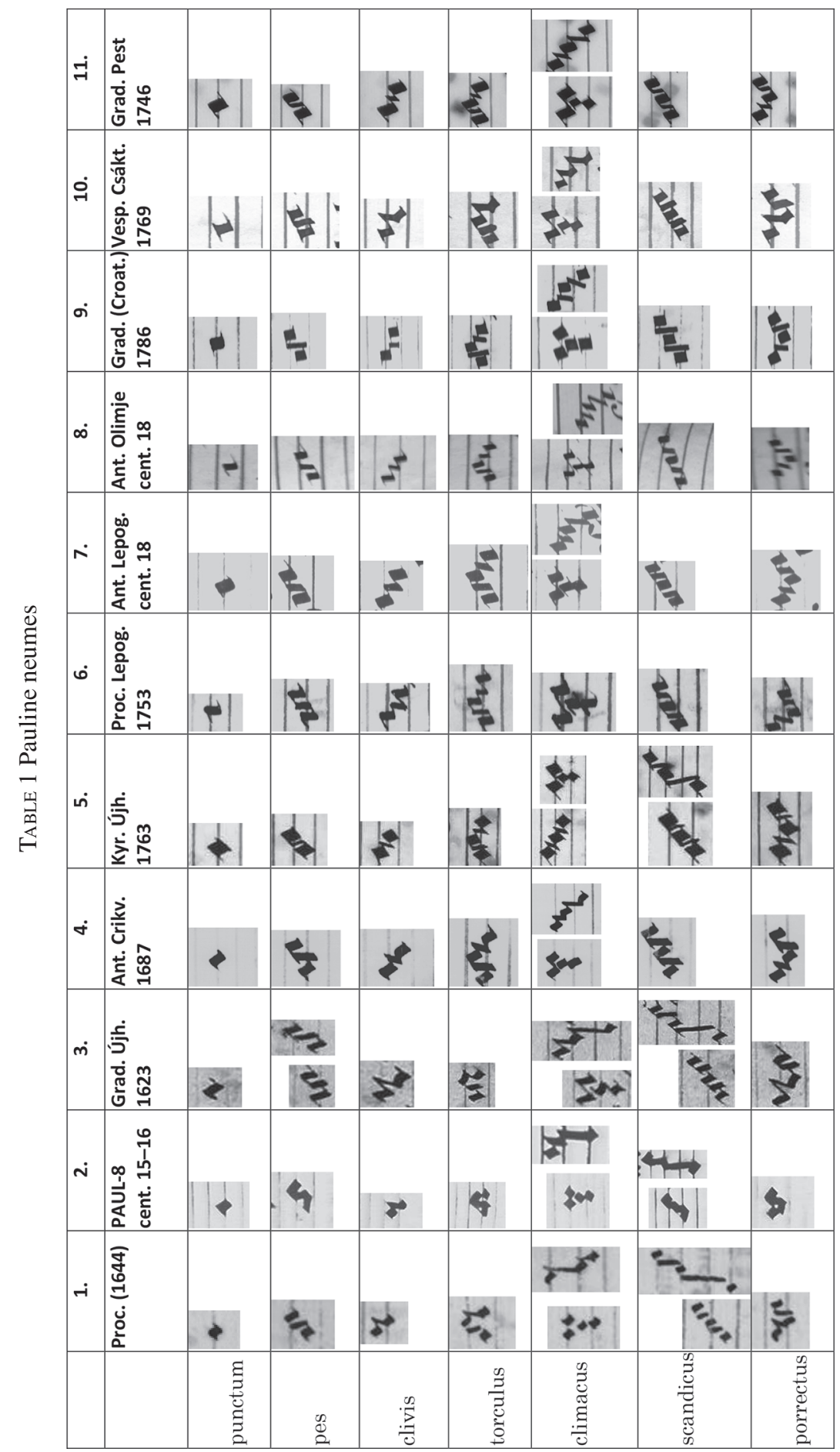


compared to the increasingly square-shaped large note heads, the whole script, including the ties, is imbued with a kind of rational angularity (see Table 1, columns 6-10). The unaffectedness, smoothness and spontaneity of the Lepoglava notation are akin to the musical writing of the Processional. Admittedly, it is evident that the appearance of the whole script and the method of linking the notes have already matured by the $18^{\text {th }}$ century. Consequently, the various elements have found their mutual new relation in the neumes. It is easily conceivable that the $18^{\text {th }}$-century Lepoglava script has developed out of a similarly flexible older form as the one found in the Processional.

The revealing of the "Croatian connection" of the Processional of 1644 could not be considered conclusive. By way of counter-verification the neumes of Lepoglava had to be compared with those of other sources of indisputably Újhely provenance. Specifically, it had to be found out how the script of the earlier Újhely Gradual fits in this picture. Can it be identified as the forerunner of a variety of writing like the $18^{\text {th }}$-century notation of Lepoglava?

A comparative analysis of both scripts proves this hypothesis as untenable. In $18^{\text {th }}$-century Lepoglava sources the punctum has more emphatic entry stokes even if the scribe does not adhere to them in each case, i.e. the use of entry strokes is inconsistent similar to the forms of the 1644 Processional. The presence or absence of the entry strokes in the drawing of the pes represents, however, a mere chronological difference which shows the neume disjunct in the 1644 Processional and conjuct in the Lepoglava sources. By contrast, in the notation of the Újhely Gradual the entry strokes constitute steady, indispensable elements of the script. The specific solution of the Újhely Gradual reminds of none of the known examples, here the linking line introducing the second note starts deeper than the line of the first punctum, which makes the layout more specific and individual. The drawing of the clivis in the Processional retains the medieval form. In the $18^{\text {th }}$-century manuscripts this sign assumes a $z$-shape, then falls more and more apart and the entry strokes and linking lines become independent, almost punctum-like elements. The clivis of the Újhely Gradual represents - despite being the oldest of the sources - a typological link between the 1644 and the $18^{\text {th }}$-century sources: the sign is already $z$-shaped but the linking line is still thin. The drawing of the climacus in the 1644 Processional and the $18^{\text {th }}$-century Lepoglava scripts is identical while in the Gradual of Újhely a pair of points appears joined first horizontally, then vertically which has neither Pauline antecedents nor analogies in later Pauline notations examined so far. ${ }^{24}$

All in all, it has been found that the $18^{\text {th }}$-century notation of Lepoglava cannot be linked to the Újhely Gradual but it can be connected to the musical script of

\footnotetext{
24. The conjunct climacus appeared in a completely restylized form in the $18^{\text {th }}$ century: its elements were drawn apart and its linking lines stressed.
} 
the Processional despite inevitable deviations due to the different dates of origin. The half-stylized notation of the Újhely Gradual may rather pass for a forerunner of the ornamental musical script of the $18^{\text {th }}$-century Hungarian Pauline sources. As a proof, it suffices to cast a glance at the geometrically precise neumatic shapes of the $18^{\text {th }}$-century Kyrial of Ujhely and the Pauline Gradual of Pest (Table 1, columns 5 and 11).

\section{Liturgical content}

The liturgical chant repertory of Oct. Lat. 794 agrees only in part with the collective title of the source: Processional. Apart from the post-Tridentine chant repertory for processional ceremonies, the volume comprises a large group of additional items prescribed for the Office and the Mass. Complying with the Gregorian liturgy's loss of importance after the Council, the book holds freely chosen, transformed and popular items, mainly typically syllabic simple melodies easy to remember, such as Vespers antiphons, Compline chants, hymns, the Te Deum, troped Marian antiphons, a tonary, Credo-, Pater noster-, Preface and capitulum-tones, Christmas and Easter invitatories, Laments and the Passional at the end of the volume..$^{25}$ The designation Cantionale or Compendium for the fashionable "mixed" book genres of the time would better express the essence and function of the volume as it much more strives to meet the general demands of the contemporary plainchant practice and to publish a collection of the most popular liturgical chants than to put into writing the processional chant repertory. Albeit the Processionals functioning as supplementary books were not homogeneous in content in the Middle Ages either - a mixed chant repertory was therefore $a b$ ovo characteristic of them -, the variegation of chant selection is particularly conspicuous in the 1644 Processional. By contrast, the actual Processional unit is incomplete and is limited to the most important ceremonies, i.e. the processional chants for Purification, Palm Sunday, Easter, Rogation Day, and Corpus Christi. It records the most important chants of the Rogation procession and the Funeral ceremony but omits the processional chants of the Temporale feasts and times of lower rank as well as those belonging to the Sanctorale.

The chant selection of the Processional section follows very consistently the Tridentine reform rite: the chant material of the ceremonies completely tallies with the order of ceremonies in the Processional of Lepoglava a century later. This conformity could immediately strike as a proof of the origin of the book in Lepoglava; however, it is more probable that we have to do in both instances with the common, homogeneous Pauline version of the post-Tridentine processional

25. The liturgical content of the Processional is published at the end of the study as Appendix 2. 
ceremony and not with a local speciality. On the other hand, the part containing the material of the rogation processional is undoubtedly relevant for the assignation of the Processional. Together with the rubrics it seems to be a local addendum already at first sight. This section contains pertinent chant items and supplications for the scenes of the stations in veneration of the own saint of the given scene in each case (Plate 3$){ }^{26}$

On Rogation Days or Cross Week $^{27}$ the processions could cover larger than usual distances to reach their destination, a church, chapel or cross: the locations of the stations could be several kilometers apart. This complicates the redrawing of the route of a certain procession but it also helps to identify it, since the set of venues can be specific to a particular monastery.

On folio $87 \mathrm{v}$ of the source, after the inscription In Rogationibus de Sancto Spiritu Antiphona, there follow chants in veneration of the Holy Spirit, of the Blessed Virgin Mary, then of St. John the Baptist and St. George. ${ }^{28}$ (The $18^{\text {th }}$-century Processional of Lepoglava does not contain this addendum.) This series can be successfully interpreted only in terms of concrete locations, i.e. on the assumption that the specific choice and order of the holy entities to be venerated are connected with the environment of a certain ecclesiastical institution. To put it unequivocally: the question is whether the rogation data of the book allow identifying a Pauline monastery that has churches/chapels/crosses in its narrower environment titled the Holy Spirit, the Blessed Virgin Mary, St. John the Baptist and St. George. Since an inscription in the Processional connects it with the town (Sátoralja)újhely in northern Hungary and Lepoglava in Croatia emerged in the course of the paleographic analysis as another possible place of provenance, routes of the Rogation procession at both places had to be examined.

The quest for appropriate ecclesiastical institutions around Újhely proved to be unfruitful and the provenance of the source from there became extremely dubious. Several Pauline monasteries are known to have existed in the environment of the Újhely monastery. They were, however, destinations difficult to reach due to the configuration of the terrain and except for the Marian convent in Gönc their titulars do not agree with those named in the Processional. Though the farther lying monastery of Kurityán had St. John the Baptist as its titular and the "Szent léleki" [Holy Spirit] convent was situated close to it, ${ }^{29}$ they were presumably outside the range of a customary procession, not to speak of the fact that they were

26. As far as the structure is concerned, the rogation procession agrees with the procession held on St. Mark's day, which belongs to the more ancient litanies also called litaniae maiores as opposed to the rogation known under the name litaniae minores. In both cases the procession leaves for the designated place by singing the All Saints litany. There a Mass is read and a sermon is given in veneration of the patron saint followed by an antiphon and rogation in his or her honour.

27. Monday, Tuesday and Wednesday before Ascension Day.

28. Antiphons Veni Sancte Spiritus, Regina coeli laetare, Iste puer magnus and Lux perpetua lucebit.

29. Founded in 1312. See Kisbán, A magyar Pálosrend története, vol. I, 55-61, 322. 
Plate 3 First antiphon of the Rogation-addendum, f. 87v

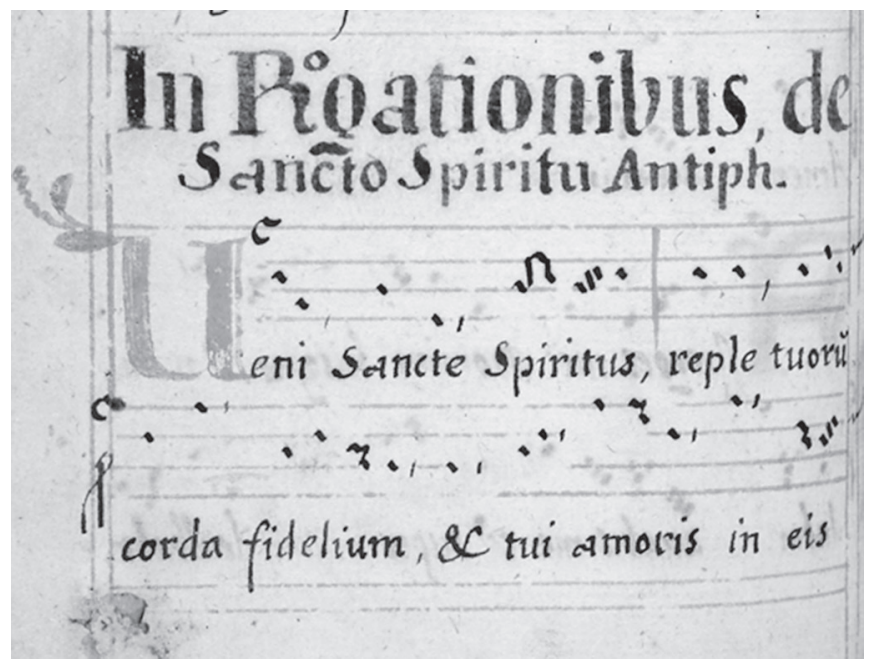

completely depopulated once for all in the 1500s. Historical sources only mention the church consecrated to St. Emeric in the vicinity of the St. Giles (Aegidius) convent of Sátoraljaújhely. ${ }^{30}$

Investigations regarding Lepoglava seemed more promising. The life and liturgical customs of the Paulines there are very well known. ${ }^{31}$ Thanks to its aristocratic patrons such as the Counts of Cilli (Hungarian Cillei), János Corvinus and the Frankopan (Hungarian Frangepán) family, the monastery founded about 1400 and named after the Blessed Virgin Mary of the Assumption ${ }^{32}$ was raised to the rank of vicariate back in 1504. Lepoglava was hit hard by the Ottoman invasion. The monastery was seriously damaged in 1481 and 1640. In 1492 János Corvinus had the entire complex reconstructed and transformed to a fortress. In 1640 it suffered serious losses again but the construction of a new Baroque, three-winged,

30. See András Vályi, "Újhely,” in Magyar Országnak leírása [Description of Hungary] (Buda: Királyi Universitás, 1799), vol. III, 556.

31. In connection with Lepoglava the following literature was consulted: Kisbán, A magyar Pálosrend története, vol. I, 55-61; Acta Monast. de Lepoglava (Hungarian State Archives); Kamilo Dočkal, Povijest pavlinskog samostana Blažene djevice Marije u Lepoglavi [History of the Pauline Monastery of the Blessed Virgin Mary in Lepoglava] (Zagreb: Glas Koncila, 1953); Zorislav Horvat, "Gotička architektura pavlinskog samostana u Lepoglavi" [Gothic architecture of the Pauline Monastery in Lepoglava], Kaj. Graditeljsko nasljeđe [Built Heritage], Lepoglava III, 5 (1982), 3-35; Petar Puhmajer, "Izgradnja i preobrazbe kompleksa pavlinskog samostana i crkve sv. Marije u Lepoglavi" [Construction and transformation of the Pauline monastery complex and the Church of St. Mary in Lepoglava], Godišnjak zaštite spomenika kulture Hrvatske [The preservation of cultural heritage in Croatia] $37 / 38$ (2013), 81-100; Tajana Pleše, "Medieval Pauline Monasteries in North-Western Croatia. Lepoglava Monastery of the Blessed Virgin Mary (1400)," in Der Paulinenorden. Geschichte, Geist, Kultur (Budapest: Szent István Társulat, 2010), 439-458.

32. It was consecrated in 1415 by Eberhard Alben, the Bishop of Zagreb. See Tajana Pleše, "Medieval Pauline Monasteries in North-Western Croatia," 445. 
three-story building was already in progress in $1650 .{ }^{33}$ Thus, during the Ottoman occupation of Hungary Lepoglava enjoyed a relative continuity of the Pauline way of life and became perhaps the most important Pauline centre of the Hungarian province. The treasury of the Order of St. Paul was put in safety there when the central monasteries of the country became destroyed and even the general's seat was transferred to the safer Lepoglava in 1570 . This monastery was designated to become the regular scene of the general chapters.

As for the processional topography of the territory on which the present investigation is focused, Kisbán mentions several nearby chapels outside the walls of the Lepoglava monastery. The oldest ones are St. George's chapel founded in 1400 and St. Anna's chapel erected by the superior János Zaicz in 1612; the latter was later renamed after St. John the Baptist. The rogation's description on the verso of folio 87, where an antiphon and an oration in veneration of both St. George and St. John the Baptist can be found, completely tallies with these data. Since these titulars (particularly George) do not belong to the frequently used ones, their joint appearance provides an almost conclusive evidence for the identification of Lepoglava as the procession's starting point. Identifying the two other processional destinations in the book, the Blessed Virgin Mary and the Holy Spirit did not prove particularly complicated: once again the topographic sections of the monastery's history proved revealing. The chant and supplication in veneration of the Blessed Virgin Mary may refer to the monastery's patron saint but other choices are also conceivable. In 1641 - that is three years before the date indicated in the Processional - the one-time St. Valentine's chapel was restored under Márton Borkovics' direction and the devotional statue of the Blessed Virgin Mary found on the mountain Veternica some kilometers southwards was deposited there. The question whether it was the destination of the procession with the titular Blessed Virgin Mary cannot be unambiguously answered. The station in veneration of the Holy Spirit may have been either the Chapel of the Holy Spirit on the mountain Ravna Gora in Bedjan, lying rather remotely from Lepoglava, or a near-by location. New archeological findings make it likely that there existed a Holy Spirit Chapel in the eastern wing of the medieval church of Lepoglava consecrated by Ludovic Teck, the Patriarch of Aquileia, in $1426 .{ }^{34}$ This chapel, being part of the church, may have been the first station of the ceremony after which the procession left the church and Mary's, George's, and St. John the Baptist's chapels were visited in succession. Taking into consideration the joint presence and convenient closeness of the stations, it is hard to believe that the titulars of the "Processional of Újhely" should not have assigned destinations to the Lepoglava procession. 
Another remarkable section in the Processional refers unequivocally to the Croatian provenance. The last unit of the book is a notated Passional in a Slavic language comprising the St. Matthew and St. John Passions (Plate 4). ${ }^{35}$ The Slavic language was described by Szendrei mechanically as Slovak, obviously due to the Újhely localization. ${ }^{36}$ In reality, the language of the Passional is not Slovak but Croatian. This means that the volume contains a substantial contingent of ca. 33 folios related to Croatia, making up $23 \%$ of its whole bulk. As for the text, a $17^{\text {th }}$-century Croatian-language Passional of Zagreb, discovered in the collection of the Zagreb National and University Library in 2010, can be instrumental in its identification. This source, inscribed Passionale Croaticum Almae Ecclesiae Zagrabiense ... Anno 1683, ${ }^{37}$ contains the same text. The melody is also closely related to the Pauline one confirming the approximate age and provenance of the Processional's Passional.

The question now arises: who entered the supplement into the book? To answer it, one has to bear in mind that the Passional is not an appendix in the traditional meaning of the word because the scripts of both its text and music completely agree with the writing style of the main text of the Processional. That the Passional was not added subsequently to the basic source but was part of the most essential script layer of the corpus implies that it was written by the same Pauline monk at the same time and in the same place as the rest of the book. If, however, the Passional cannot be detached from the corpus, the Processional itself cannot be from Újhely - it would have been as inconceivable to sing a Croatian-language Passion there as to hold a Rogation procession that had no local stations. Its scribe, the unknown Pauline monk must have been active in a Croatian monastery, by all probability in Lepoglava.

\section{Historical background}

At this point it is necessary to consider how and under what circumstances a notated chantbook made the journey of about five hundred kilometers from its presumed place of origin, Lepoglava in Croatia to Újhely in Northern Hungary. In the Middle Ages it was a general custom in the Hungarian Church, particularly among monasteries of the same order, to donate liturgical books, since not all of them had a professional copying workshop. The Pauline workshops often accepted commissions as well and met both external and internal demands for liturgical books. In the wake of the historical disasters in the $16^{\text {th }}-17^{\text {th }}$ centuries, lending

35. Ff. 111r Secundum Matheum, 136v Secundum Johannem.

36. Szendrei, A magyar középkor hangjegyes forrásai, 70.

37. Nacionalna i sveučilišna knjižnica, Zagreb. Shelf-mark: R 3006. 


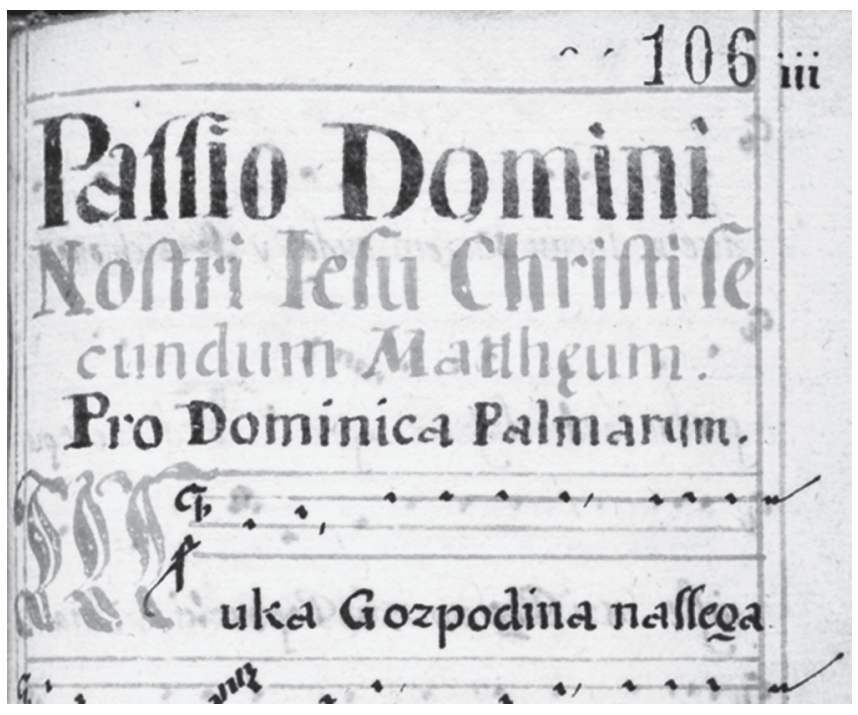

and donating books - especially liturgical ones containing the new Tridentine rite - assumed particular significance. To help churches threatened by the advance of the Ottomans and impoverished by the progress of Protestantism as well as to secure their uninterrupted religious life were the preconditions of the survival of monasteries in precarious situation. It must have been a particular concern to support certain convents such as the monastery of Sátoraljaújhely, which played a strategic role as the north-eastern border castle of the Paulines, especially because this convent subsisted in a more difficult situation than any of the communities in the more protected parts of the country.

In order to be able to assess the fate and importance of Sátoraljaújhely in the Hungarian Church and the Hungarian Pauline province, we must go back to its establishment. Founded by King Béla IV in 1248, being thus ca. 150 years older than the Lepoglava monastery, the convent of Újhely named after the abbot St. Giles achieved considerable rank in the Middle Ages. ${ }^{38}$ Újhely was destroyed, among several other monasteries, during the Ottoman invasion of the country. The monks returning later to the Zemplén region, which was widely known to be anti-Catholic, had to fight with Protestantism as well: the reconstruction and continuous maintenance of the monastery was thwarted by the looting and har-

38. This can be seen in the continuous growth of landed property, increased in 1335 by the donation of Margaret, Princess of Slavonia, sister-in-law of King Louis the Great. In 1350 King Louis the Great himself consolidated its estates. By 1501 the church dedicated to St. Giles had already been erected. See Kisbán, A magyar Pálosrend története, vol. I, 19, 90. According to Kisbán, the monastery may have had a library of considerable stock as well; its wealth can be traced unto the mid-15 $5^{\text {th }}$ century. Ibid., vol. II, 155. 
assment of the Protestant Hungarian aristocrats' armed forces. An improvement set in with the activity of the Istrian Simon Bratulics, general of Lepoglava, later bishop of Zagreb, whose main ambition was to rebuild the Pauline monasteries devastated in the early 1600 s and to recover their possessions. In 1610 he rescued the convent of Újhely and its estates for the order which had been confiscated by István Bocskai's supporters, the "hajduk". ${ }^{39}$ General Bratulics' endeavours may have represented the first concrete connection between Lepoglava and Újhely: in the course of the 1610 reconstruction and the reestablishment of religious activities, Pauline possessions must have been transferred from the prosperous Lepoglava centre to Újhely - among them obviously liturgical books as well. However, lootings continued to constitute a steady menace in the region populated by Protestants and by the 1630s Sátoraljaújhely was once again in a disastrous state. After repeated assaults by György Rákóczi's soldiers, general Miklós Stassewski ordered the reconstruction of the Újhely monastery in $1638 .{ }^{40}$ This date is very close to 1644 , the year when the Processional is supposed to have reached Újhely.

When fitting together the mosaics of Pauline history, one must not forget that Lepoglava itself was rebuilt from the ruins in the $1640 \mathrm{~s},{ }^{41}$ a fact strengthening rather than weakening the hypothesis of the Processional's originating there. Thanks to generous donations Lepoglava underwent a genuine revival and could refresh its own holdings. In the monastery new books were made probably not only for local use but for faraway monasteries as well. However, the definitely Croatian character of the Pauline Processional shows unambiguously that it cannot have been expressly prepared for Újhely and sent to the north. It is much more conceivable that it answered an urgent request for prompt assistance and reached the impoverished region through a private intermediary.

The transfer and donation of liturgical books may have been connected to the effort of Rome to initiate a renewal in the liturgical life of the Paulines. After long preparations, a reform constitution of the Order of St. Paul the First Hermit was affirmed and approved by Pope Urban VIII in 1643 and printed in Rome the same year. The reform of the order emphatically demanded the reorganization and consolidation of the Pauline monasteries - including Újhely. Strictly regulated monastic life together with a reestablishment of liturgical discipline were stipulated as necessary basic conditions of the survival of the order. It is only logical that the central monastery endeavoured to consolidate the weakened convents (and the order's weakened discipline) by invigorating liturgical life also by means of supply-

39. The army of the hajduk (in Hungarian "hajdú," a kind of freelance, infantry soldiers) was recruited by István Bocskai, a Calvinist nobleman, Lord of Bihar, Duke of Transylvania, who led them against the Habsburgs in 1604-1606.

40. Ibid., vol. II, 213-216.

41. Tajana Pleše, "Medieval Pauline Monasteries in North-Western Croatia," 445. 
ing the liturgical books that were lacking. ${ }^{42}$ Conjointly with the new Pauline constitution new liturgical books may have been compiled in the centre and distributed among the Pauline monasteries (remember that the year of publication of the new constitution and the date which appears in the Processional are very close). ${ }^{43}$

\section{Musical features}

All that remained after this discussion was to examine whether the musical analysis would contradict or corroborate the liturgical and historical argumentation. A crucial question was how the melodies in the book related to the pre- and post-Council Pauline chant material and whether musical relations between the sources of the Croatian province and the "Újhely Processional" could be detected at all. In view of the uninterrupted and homogeneous Pauline tradition, one could not reckon with a marked difference between the musical variants. The musical comparison provided nevertheless an opportunity for discerning a kind of common "Croatian" character and for perceiving the difference to the musical forms used in the Hungarian province.

The evaluation of the musical features was complicated by the uneven chronological distribution of the sources, which had to be taken into consideration. It is an interesting issue, only loosely connected to the matter of provenance, that certain items of the chant underwent considerable changes during the centuries while others became but little modified from the Middle Ages to the $18^{\text {th }}$ century. The items preserved in a more archaic state include the responsoria prolixa with complicated, ornamented melodic line used as processional chants; the melody of Ite in orbem or Felix namque sung during the Rogation procession agrees, for example, almost exactly in the Pauline sources originating at different times. ${ }^{44}$ However, the comparative analysis of variants of the monumental responsory Verbum caro contradicts this statement. The 1644 Processional as key source prescribes a variant very close to the medieval version showing divergences merely

42. This theory is corroborated by the fact that Márton Borkovics, the superior of Lepoglava at the time succeeding Stassewski as general of the order, was a committed supporter of the reform and the constitution, and a continuer of the renewal.

43. The $17^{\text {th }}$ century represented the lowest point in the history of the Order of St. Paul (see Kisbán, A magyar Pálosrend története, vol. II, 208-209). Due to the unfavourable conditions in the Order, the Holy See appointed the Jesuit Péter Pázmány to the post of Apostolic Visitor. At the 1629 council of the order Pázmány submitted two suggestions: either to abolish the order altogether or to put it under the authority of the Dominicans as there seemed little chance that reforms of the order could be carried out effectively. Following immediate stringent measures taken by general Gruskovics, the Pope yielded and ordered the visitation of the whole order again in 1632 and later the convocation of the grand chapter of the order to adopt measures necessary for its survival, including the renewal of its constitution.

44. Only one considerable difference can be observed: the $18^{\text {th }}$-century Processional of Lepoglava has a shortened version (f. 41v). 
in some insignificant points. ${ }^{45}$ A comparison of the Processional's melody with the post-Council versions already shows considerable changes. For example, the second line begins with Et vidimus gloriam instead of Cujus gloriam vidimus in the $18^{\text {th }}$-century sources: it is modified melodically and its verse chose another text (Example 1). The $18^{\text {th }}$-century variants are not homogeneous in themselves either. Each of the two $18^{\text {th }}$-century Lepoglava sources contains a different variant, depending on the liturgical position of the item, i.e. whether it is sung at the Christmas Office or during the Rogation procession. The Christmas Verbum caro in the $18^{\text {th }}$-century Antiphoner of Lepoglava is on the whole closer to the archaic form and the 1644 melody than to the processional melody Verbum caro of the $18^{\text {th }}$-century Processional of Lepoglava. The fact that the melody got hardly modernized in the Christmas function during the centuries leads to the conclusion that the Christmas Matins abandoned it later, but it remained in use as a processional chant - mostly in a shortened form. ${ }^{46}$

What makes the unraveling of the Croatian and Hungarian connections of the "Újhely Processional" really difficult is the scarcity of surviving processional chant collections of the order. Hence for purposes of comparison, items had to be selected that occur - often in different functions - in books of diverse genres such as the Gradual and the Antiphoner. In the comparison the retrospective Pauline sources from Lepoglava had to be included: i.e. an Antiphoner and a Processional from the $18^{\text {th }}$ century, ${ }^{47}$ as well as additional medieval and Baroque volumes of the Order of St. Paul from Croatia and Hungary. From Sátoraljaújhely the musical repertories of a Gradual dating from 1623 and that of the 1763 Kyrial are available - showing unfortunately very little overlapping in contents, the Kyrial and the Processional having no single item in common. Consequently, for purposes of comparison only some antiphons for the consecration of water could provide points of departure.

First the Easter antiphon Vidi aquam and the Asperges antiphons in per annum time were collated. The versions of the syllabical Asperges antiphons do not differ significantly in the studied sources. The variants of Vidi aquam being somewhat dissimilar in musical style and displaying a more vivid melodic line seemed to be more interesting (Example 2). As far as the melodic versions of the item are concerned, the 1644 Processional is note by note identical with the $18^{\text {th }}$-century Lepoglava variant but differs on seemingly significant points from the version of the Újhely Gradual: variants of this type include the shortening of musical forms,

45. PAUL-8, Częstochowa Cantuale (see the list of sources in Appendix 3).

46. A similar observation could be made in the case of the antiphon Vespere autem sabbati; in the $18^{\text {th }}$ century its processional version shows considerable differences from the melodic variant of the 1644 Processional and from the $18^{\text {th }}$-century Vespers item on Holy Saturday (f. 34v). Thus a late variation connected with the change of function can be observed in this case, too.

47. HR-Zu R 3612; HR-Zu R 3004. 
EXAMPLE 1 Melodic variants of Great Responsory Verbum caro

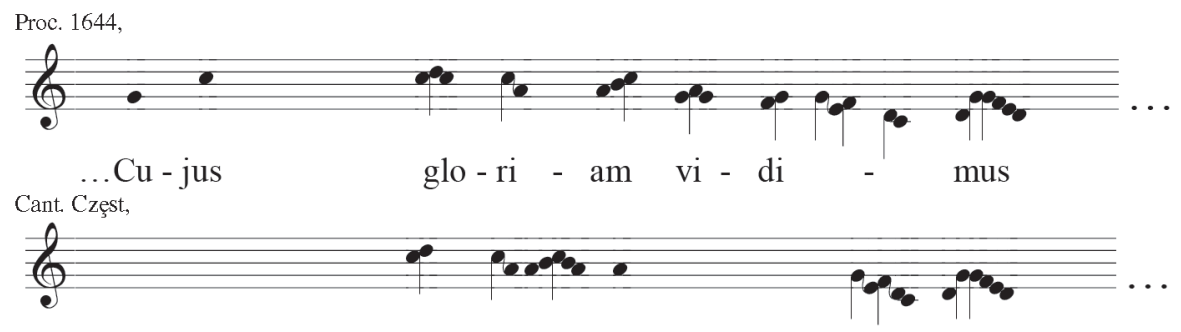

PAUL-8,

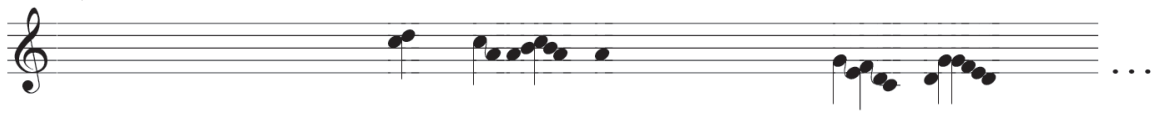

Ant. Lepog.,

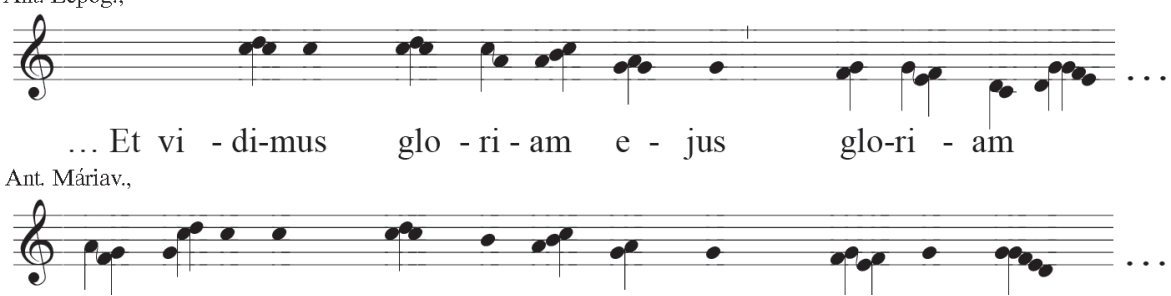

the reshaping of cadences or the inconsistency of the pentatonic or diatonic versions of psalm formulas.

The melody of the Te Deum, which remained popular after the Council of Trent, is found in a lot of retrospective sources and therefore it lends itself particularly well for comparative study. The typical syllabic musical lines can explain why the piece is fairly homogeneous in most sources. The difference in style resulting from the age of the given melodic variant is conspicuous while the variation attributable to topographical position and hence more relevant for the present topic can only be conjectured. The Processional's variant can be compared to the medieval Pauline melody (PAUL-8), a 1687 Croatian Pauline melody from Crikvenica as well as to the $18^{\text {th }}$-century Croatian and Hungarian Pauline versions (Processional of Lepoglava and Kyrial of Újhely respectively). A significant difference between the post-medieval sources appears to be the lack of the typically "Hungarian" turn of the closing formula, i.e. transposed upwards by a fourth, and thus closing higher than the basic tone. In its stead the standard Roman-curial version can be found, that is the section beginning with Per singulos remains in the main tone.

From the second half of the $17^{\text {th }}$ century onwards, the relationship between text and melody changed significantly compared to the original medieval chant version, a fact that explains the majority of the variants of Te Deum melody. In the 
EXAmple 2 Antiphon Vidi aquam (varied motives), Újhelyi Gradual - Processional (1644)

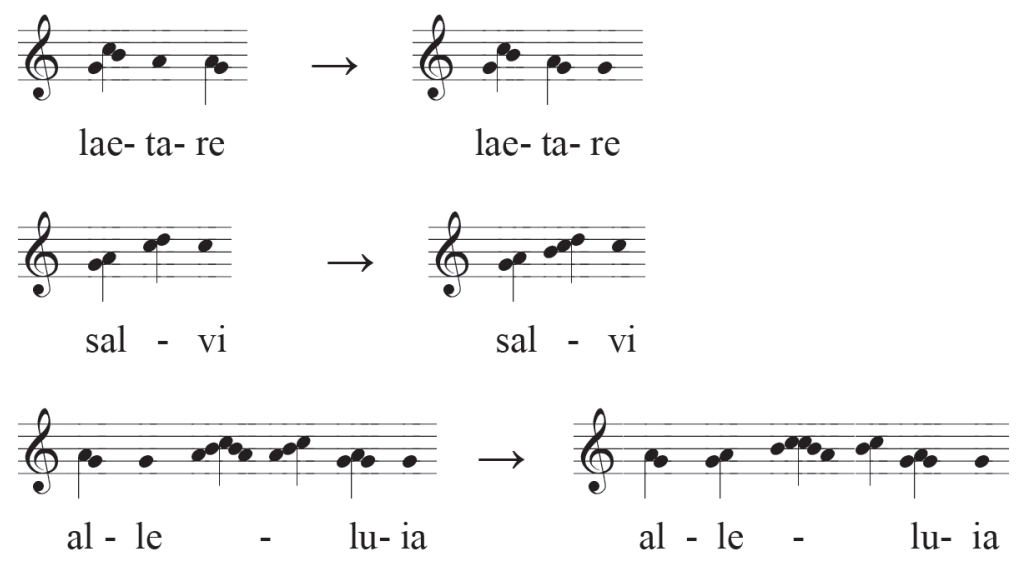

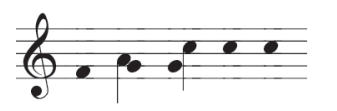

Glo-ri-a Patri

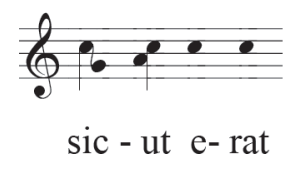

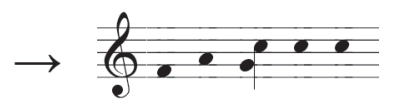

Glo-ri-a Patri

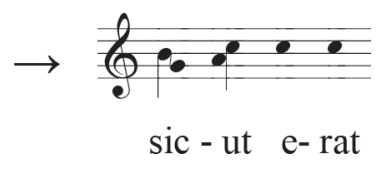

melodies reshaped according to the principles of humanistic aesthetics, the melisma was removed from the unaccented syllables and rearranged. This principle brought forth the transformation of the strategically important cadences (Example $3 a$ ). The later the variant is, the more resolute the intention seems to be to carry out such a modernization: the $17^{\text {th }}$-century Processional gets to a mixed, transitional level of reshaping compared to the medieval forms on one hand, and the $18^{\text {th }}$-century variants on the other. Since the archaic outlines still remain powerful in it, the source often holds identical formulas with the medieval ones (Example $3 b$ ). Then again, in the Te Deum of the Processional modern melodic turns can also be detected, linking the source to the later Pauline variants (Example 3c). The similarity with the ca. 40 years younger variant of the Antiphoner of Crikvenica is particularly striking. As a result, the Te Deum neither does nor can offer variation types that could be called "Lepoglavan". Nevertheless the Croatian sources appear on the whole in a more archaic state, particularly in comparison with the $18^{\text {th }}$-century Hungarian Pauline sources. Hence the closeness of the Crikvenica source and the "Újhely Processional" seems to be more than a mere similarity resulting from chronological proximity. 
The analysis of the Marian antiphon Regina coeli laetare strongly underlines the assumptions that the Processional's item is close to the $18^{\text {th }}$-century Croatian melodic version. Both contain a troped antiphon and the melody of the trope (Alme Domine nate maris Deo) is completely identical. Not only the trope creates community, so does the antiphon melody, which strikingly agrees in the Croatian Pauline sources. By contrast, the Kyrial of Újhely has a form displaying a lot of differences (Example 4).

\section{Example 3a Parts of the Te Deum}

Processional (1644)

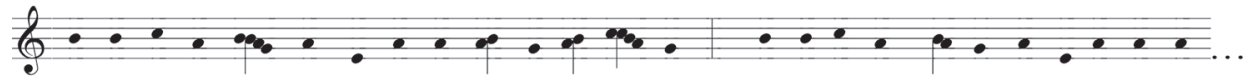

Te ae-ternum Patrem omnis ter-ra ve-ne-ra-tur. Ti -bi o-mnes An-ge-li ti-bi coe- li

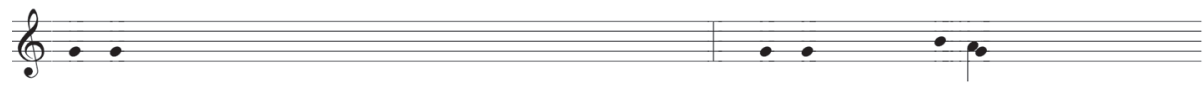

PAUL-8
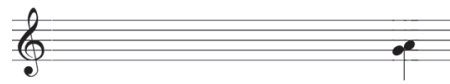

Ant. Crikv.

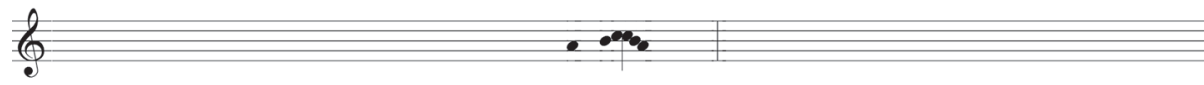

Proc. Lepogl.

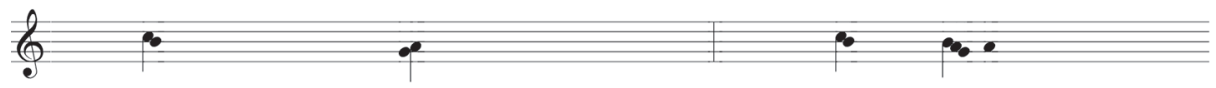

Kyr. Újh.

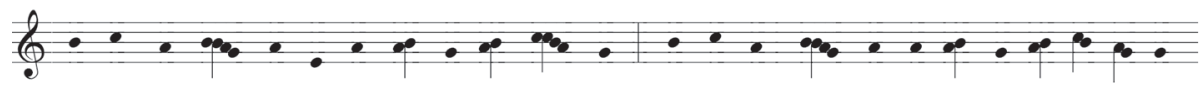

Te glo -ri - o - sus A -po -sto- lo-rum cho- rus. Te Pro-phe - ta - rum lau-da - bi-lis nu-merus.
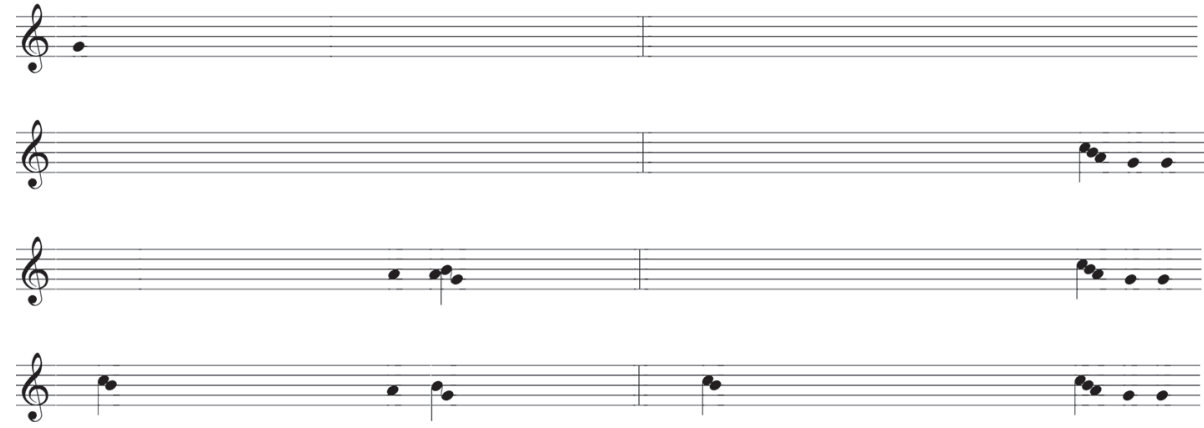
Example 3b Parts of the Te Deum (continuation)

Proc. (1644) + PAUL-8 (identical):

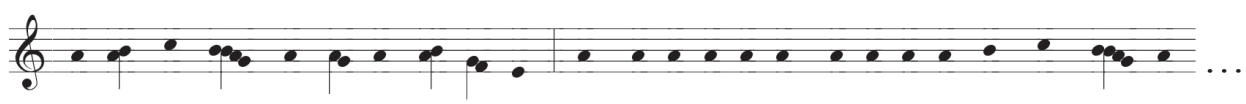

Ju-dex cre- de - ris es- se ven-tu-rus. Te ergo quesumus tuis fa-mu-lis sub-ve - ni Ant. Crikv.+ Proc. Lepogl.:

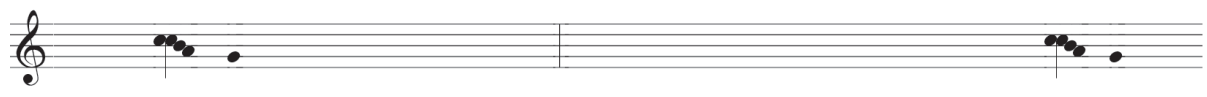

Kyr. Újh.

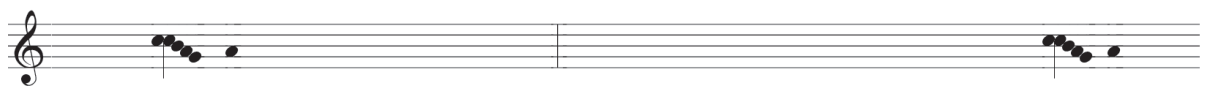

Example 3c Parts of the Te Deum (end)

Proc. (1644), PAUL-8 vs. other sources:

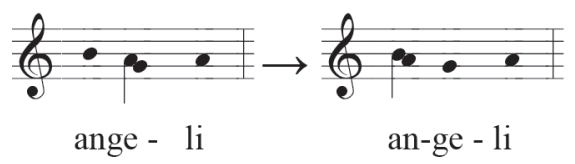

PAUL-8 vs. Proc. (1644):

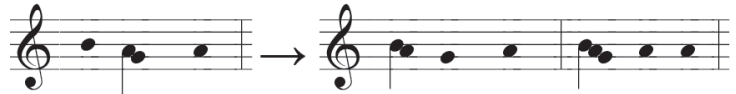

Se-ra - phin Se- ra -phin
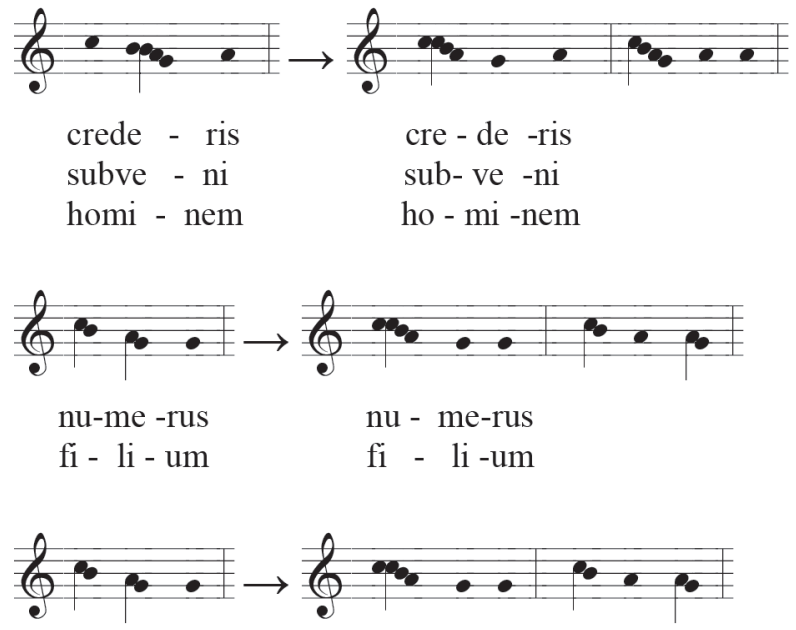

Sa- ba- oth Sa - ba-oth 
In the matter of provenance the musical comparison of the Tonary sections may prove decisive. As was said above, due to their compilation character the $17^{\text {th }}-18^{\text {th }}$-century Pauline chantbooks comprised material alien to the type of book indicated on the title page: they could contain practically anything sung in the Divine Office (musically reduced at the time) or in the Mass, or whatever may have belonged to the contemporaneous plainchant practice. Thus the Processional includes a separate Tonary section, a so-called Central European "short Tonary," which demonstrates the Modes of psalm singing (Plate 5). ${ }^{48}$ This type of Tonary, which can unfortunately be only documented in Hungary after 1526, probably goes back to a medieval Hungarian (Esztergom) Tonary unknown for posterity. As we do not know anything of the relationship between the early and late copies, all we can safely claim is that the late medieval and Baroque retrospective Paul-

EXAMPLE 4 Beginning of the antiphon Regina coeli laetare

Processional (1644)
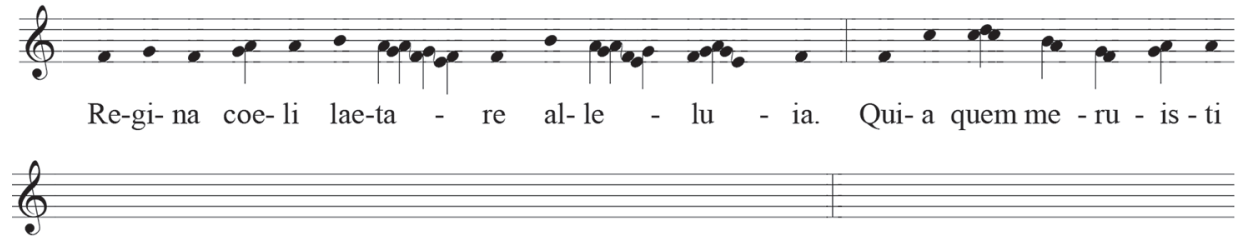

Proc. Lepogl.

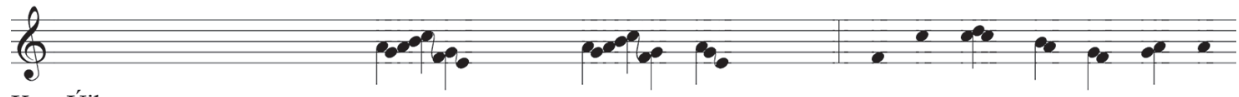

Kyr. Újh.

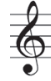

Vesp. Csákt.
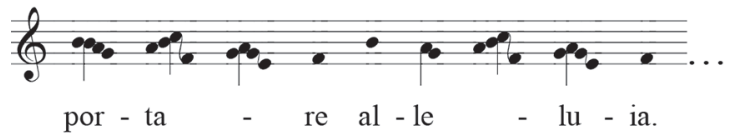

8
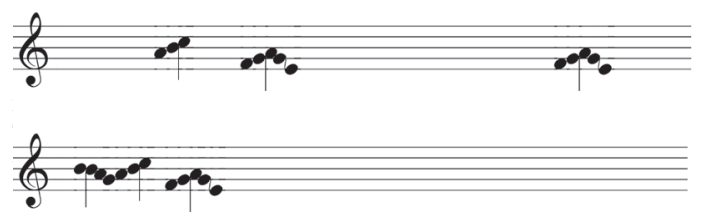


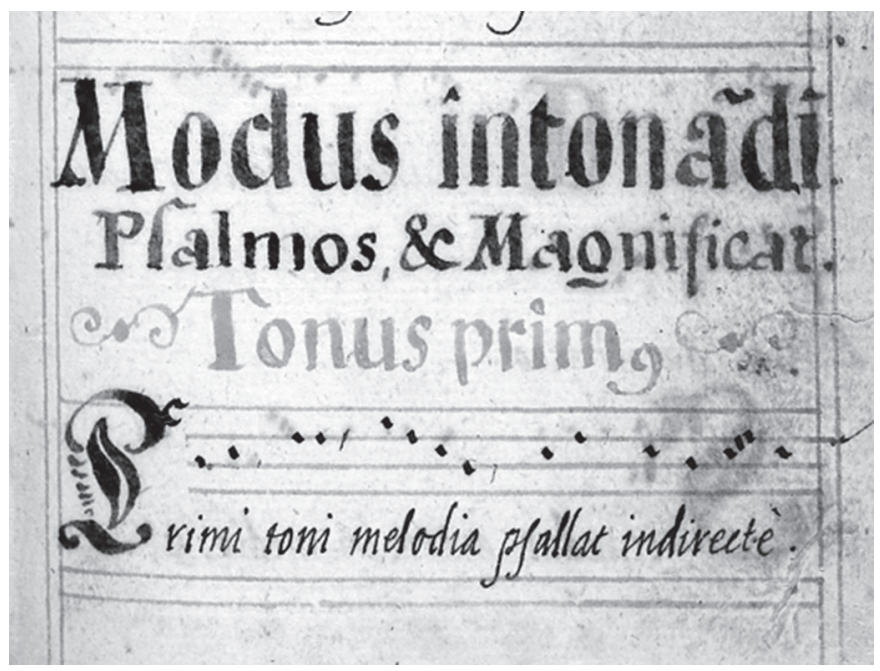

ine sources evidence the psalmodizing practice of the Order of St. Paul the First Hermit in the period after 1526.

For musical comparison the relevant sections of the Cantuale of Częstochowa (16 ${ }^{\text {th }}$ century) and the Antiphoner from Crikvenica in Croatia (1687) can be used. Example 5 shows variants of the pattern melodies and differentiae in Mode 1 and demonstrates well the wide range of minor variations in the two sources which are of identical root and belong to a common local tradition. Still, one can easily detect the common ground, the basic musical style linking the two versions. The superficial but not negligible divergences include the differences of intonation and jubilus-melismas, the dissimilar order of the differentiae and the occasional variations in the choice of psalm text for the pattern melodies. An overall similarity between the Tonaries of the Częstochowa source and the Processional is manifest in the common pentatonic melodic turns, the quantity and quality of the differentiae and the corresponding melodic line.

A comparison of the Processional's version with the Pauline Tonary of the Istrian Crikvenica reveals, however, a completely different level of musical similarities. Surprisingly, both volumes have a practically identical version of the Tonary where the melodies and the orders equally agree. ${ }^{49}$ It is therefore evident that the Croatian volume reproduces the same copy except for some superficial note differences.

49. Considering the Tonary as a whole, only differences of some notes emerge. Some of them are, however, significant variations touching upon the issue of dialect: in the example melodies and at the differentiae in Mode 4, the Crikvenica Tonary has a diatonic version rising only to the note $b$ instead of $c$. This may go back to geographical and chronological reasons; the source was used in the Pauline border region and dates from about 40 years later than the Processional. 
Example 5 Tonary-melodies (Mode 1), 1. Processional (1644) 2. Cantuale of Częstochowa

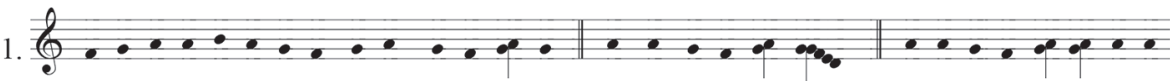

Primi toni melo-di- a psallat in di-rec-te. Differentiae.
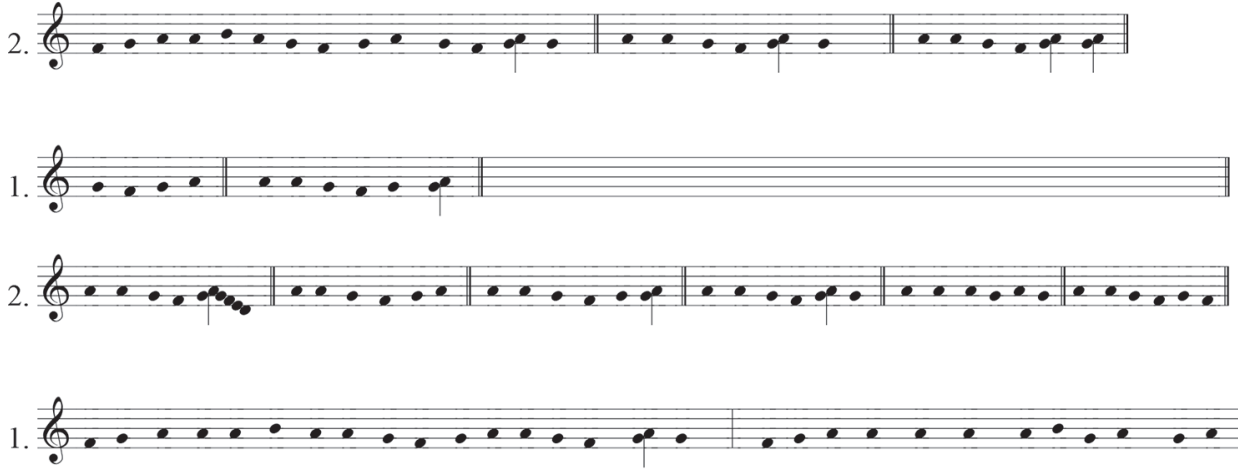

Dixit Dominus Domino meo se-de a dextris me-is. Credidi propter quod locutus sum e-go

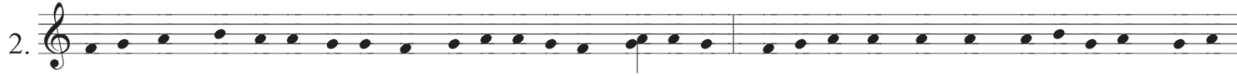

Laudate pu -e-ri Domi-num laudate nomen Domini.

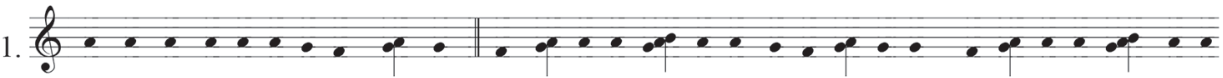
autem hu-mi- li- atus sum nimis. Magni- fi-cat a - nima mea Dominum Et exsultavit spi - ritus
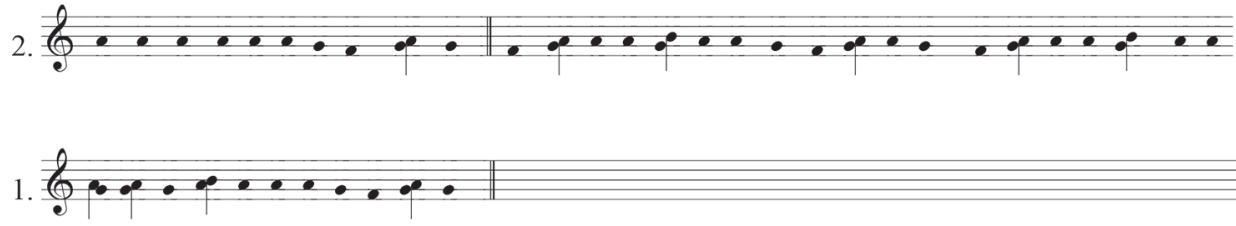
me-us in De- o sa-lu-ta-ri me- o.

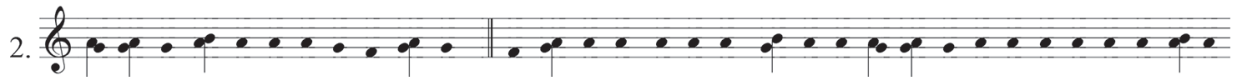
Benedictus Dominus De-us Is-ra- el quia vi-si-ta-vit et fe-cit

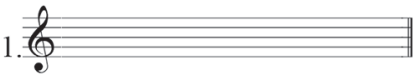

2. $8 \cdots \cdots \cdots \cdots$

redempti-o-ni ple-bi su-ae. 
The road from here onwards leads mainly over the shaky ground of theorization; nevertheless, some facts allow further speculations. Earlier research has proved that the style of the melodies in the Crikvenica chant collection is - similar to that of the $18^{\text {th }}$-century retrospective Croatian Pauline sources - strongly archaizing and deeply indebted to the medieval Gregorian chant, resulting from a more peripheral, secluded monasteric environment maintaining closer ties with its traditions. ${ }^{50}$ In Hungary, the graduated modernization of the Pauline musical style in a Tridentine humanistic spirit came off in the $17^{\text {th }}-18^{\text {th }}$ centuries, in harmony with the complete rebuilding of the ecclesiastical institutions in the Baroque era and the blossoming of Pauline life. Though the difference between the Hungarian and Croatian Pauline musical styles is more apparent in the $18^{\text {th }}$-century sources when the independence of the two provinces was officially declared, the melodic forms might have earlier begun to drift apart. Unambiguous signs of this split and the simultaneous emergence of a "Croatian musical alternative" can already be detected in the $17^{\text {th }}$-century sources. If the hypothesis that the Processional of Ujhely had originally been a volume conveying the Croatian monastic practice is accepted, the musical analysis of the Tonaries can also support the outcome of the analysis of the $17^{\text {th }}$-century Crikvenica source, namely, that the Croatian melodic forms remained practically intact from the mid-17 th to the late $18^{\text {th }}$ centuries as confirmed by several later Croatian Pauline sources on the various occasions of singing the Office and Mass in plain chant. The $17^{\text {th }}-18^{\text {th }}$-century Croatian Pauline melodic tradition, which can evidently be related to the 1643 edition of the order's new constitution, ${ }^{51}$ represents a homogeneous musical style and the musical language of the Processional of "Újhely" clearly fits into this process. Thus, the musical analysis can also bring forward cogent arguments in favour of the Croatian connection of the source, even if it cannot determine the assumed provenance from Lepoglava as unambiguously as the processional topology did.

\section{Conclusions}

The so-called "Processional of Újhely" of the Order of St. Paul the First Hermit, Oct. Lat. 794 of the National Széchényi Library whose Croatian provenance hopefully has been demonstrated beyond doubt in this paper, bears not only marginal notes testifying to its Újhely ownership but also some emendations presumably in the same hand (Plate 6). This provides indisputable proofs that the book was in use in this place; consequently, the Processional can be regarded as a relict of the

50. See Gilányi, "A hiányzó láncszem? Egy 1687-es pálos antifonále Crikvenicából."

51. F. 8v Vexilla regis prodeunt (Dominica Passionis), f. 14v Quodcumqe in orbe (Cathedra S. Petri), f. $17 \mathrm{v}$ (Petri et Pauli), f. 28 Iste confessor Domini (De Confessoribus), f. $29 \mathrm{v}$ Jesu corona virginum (De Sanctis Virginibus). 
Plate 6 Corrections to the Hymnar (H. Iste confessor Domini), f. 29r

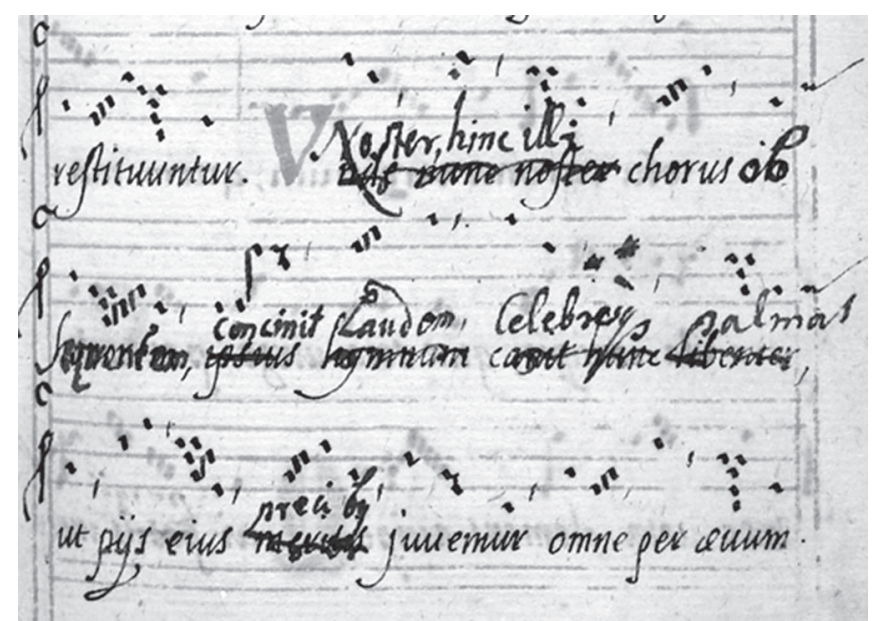

"Újhely" liturgical praxis. Sceptical readers may at this point raise the issue: if a Pauline liturgical book could be used in ceremonies by any Pauline community and the Pauline monks themselves regarded its musical content as universally Pauline and at the same time validly Tridentine, what sense does it then make to enquire about its provenance?

To this question no simple answer can be given. At the beginning of this paper it has been stated that when examining a processional, the researcher is confronted with a task that significantly differs from the analysis of an Antiphoner or a Gradual since certain particulars of the book genre may also have geographical relevance: it seems as if processions, being more peripheral actions of the liturgy, were more locally controlled. Processionals apparently provide a livelier picture of the life of a certain religious community that attached importance to defining and distinguishing itself from others by means of its own special ceremonies. It can be claimed without any doubt that the scribe of the Processional under scrutiny here clearly and deliberately indicated the origin of the volume in Croatia, and within it in Lepoglava. This seems to be proven not only by the unambiguous processional topography and the presence in the book of a Passional in Croatian language but also by the paleographical and musical analyses which helped to distinguish the retrospective liturgical practices of the Croatian and Hungarian monasteries. Obviously, the Tridentine-Pauline liturgy cannot simply be described as a strictly defined and centrally fixed practice. Even this manifoldly regulated late tradition proves to be colourful, lively and individual.

It is quite improbable that such sections of the Croatian source like the Croatian-language Passional or the processional chants adapted to the Lepoglava environment were ever used in Újhely: they cannot have had anything to do with the 
north-Hungarian border region. However, the marginal notes of the 1644 source tell another story: the Hymnar, for example, that was later actualized attests to a progressive, modern musical practice at the Hungarian Paulines as opposed to the contemporaneous but more archaic use in the Croatian monasteries. The emendations affect the text of the hymns which belonged to the most popular chants of the Tridentine liturgy. It could only have happened so that the archaic Croatian textual form of the Processional was submitted to modernization on the basis of new post-Tridentine musical principles in Hungary (in this case in Újhely).

To sum up: the re-positioning of the Processional Oct. Lat. 794 within the Pauline chant tradition called attention to the relative unity in the plainchant usage of the Pauline community which went along with a lively chronological and geographical differentiation. It has hopefully proven that the precious items of the post-medieval Pauline book culture demand a renewed examination of the sources and, if necessary, their reevaluation by making use of up-to-date methods of analysis and new technical devices. 


\section{Appendix 1}

Map of Pauline monasteries

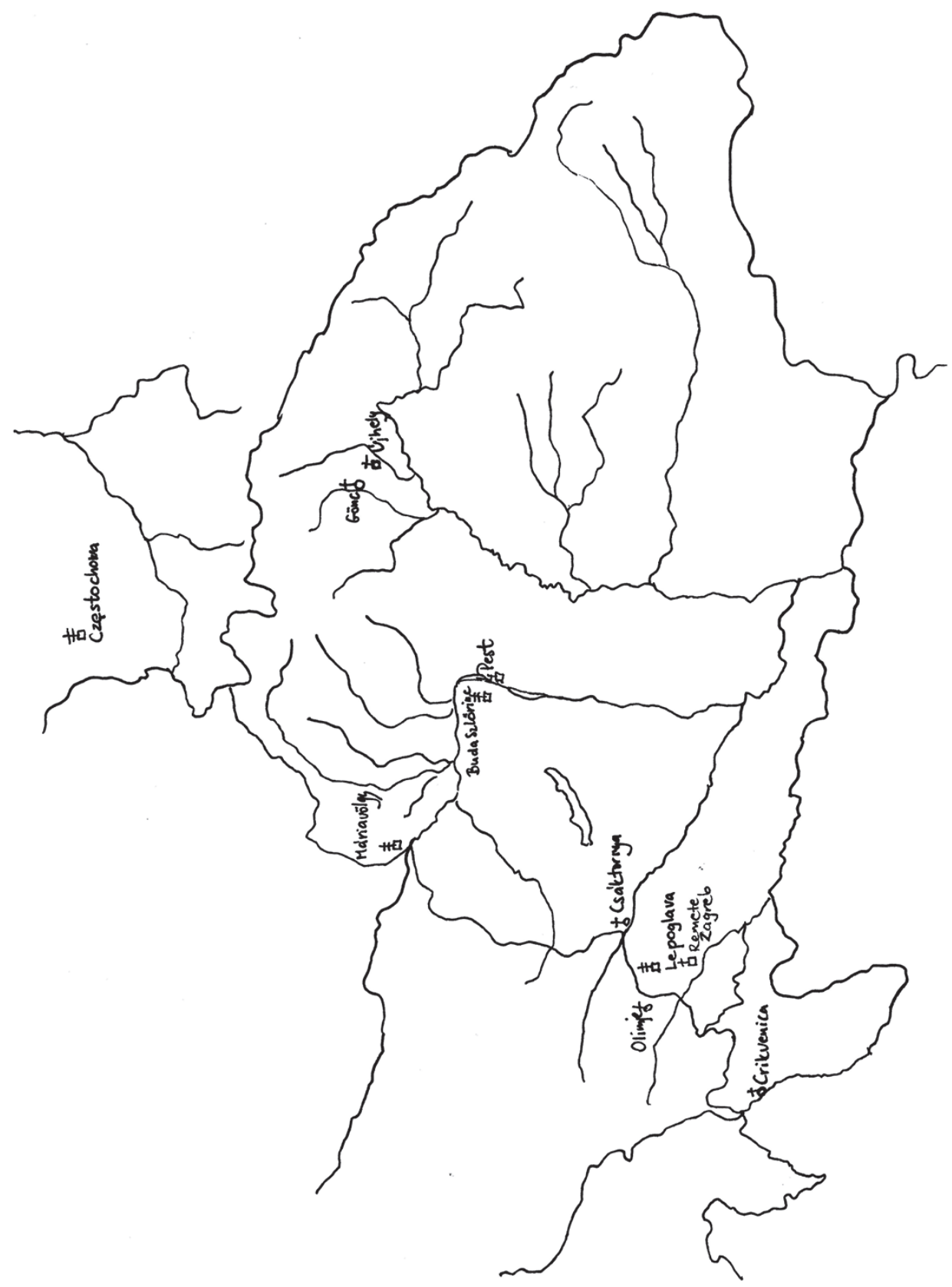




\section{Appendix 2 \\ Content of the Processional}

\begin{tabular}{|l|l|}
\hline $\mathbf{1}$ & Diebus Sabbati et Dominicis antiphonae per Annum \\
\hline $\mathbf{1 v}$ & Antiphonae ad Vesperas (Diebus Dominicis) \\
\hline $\mathbf{2}$ & $\begin{array}{l}\text { Hymnarium (ad Vesperas per Annum, in Adventu Domini, in Nativitate Domini, in } \\
\text { festo Sanctorum Innocentum, in Epiphania Domini, Diebus Sabbati per Annum, in } \\
\text { Quadragesima, in Domenica Passionis, Sabbato in Albis, in Ascensione Domini, in } \\
\text { Festo Pentecostes, Dominica Sanctis Trinitatis, in Cathedra Sancti Petri, in Conversione } \\
\text { Sancti Pauli Apostoli, in Inventione Sancte Crucis, in Nativitate S. Johannis Baptistae, } \\
\text { in Festo Ss. Apostolorum Petri et Pauli, in Festo S. Mariae Magdalenae, in Festo S. Petri } \\
\text { ad vincula, in Transfiguratione Domini, in Exaltatione S. Crucis, in Festo S. Michaelis } \\
\text { Archangeli, in Festo Omnium Sanctorum, in Festivitatibus B. M. V., Commune } \\
\text { Sanctorum, in Dedicatione Ecclesiae) }\end{array}$ \\
\hline $\mathbf{3 2 v}$ & Te Deum \\
\hline $\mathbf{3 5}$ & Benedicamus per Festa et Solemnitates \\
\hline $\mathbf{3 7}$ & Antiphonae: Regina caeli, Salve regina, Gaude Dei genitrix \\
\hline $\mathbf{3 9}$ & Modus intonandi psalmos et Magnificat \\
\hline $\mathbf{4 4}$ & Duplex tonorum compendium (Modus cantandi martyrologium) \\
\hline $\mathbf{4 6}$ & $\begin{array}{l}\text { Tonus missae, Tonus epistolae, Tonus Evangelii, Credo, Praefatio, Pater noster et } \\
\text { consecr., etc. }\end{array}$ \\
\hline $\mathbf{4 8 v}$ & Capitulum in Vesp. et Completorio \\
\hline $\mathbf{5 0}$ & Ad Complet. antiphonae, responsorio, ad Nunc Dimittis ant. \\
\hline $\mathbf{5 1}$ & In die Paschae et per octavam: Haec dies, in Festis S. Mariae Hymnus: Te lucis \\
\hline $\mathbf{5 2 v}$ & Responsorium ad Primam per Annum et tempore Paschae \\
\hline $\mathbf{5 3 v}$ & $\begin{array}{l}\text { Processionale (in Purificatione B. M. V., in Dominica Palmarum, in Ressurectione } \\
\text { Domini, in Rogationibus, in Festo Sancti Marci, in Ascensione Domini, in Festo } \\
\text { Corporis Christi) }\end{array}$ \\
\hline $\mathbf{7 8}$ & Ritus sepeliendi mortuorum \\
\hline $\mathbf{8 2}$ & Invintatorii \\
\hline $\mathbf{8 6}$ & Ad Aspersionem Aquae Benedictae: Vidi aquam, Asperges \\
\hline $\mathbf{8 7 v}$ & In Rogationibus Quatuor Antiphonae \\
\hline $\mathbf{8 9 v}$ & Lamentatio Jeremiae \\
\hline $\mathbf{1 0 5}$ & Feria Sexta in Parasceves. Improp.: Popule meus, item Ecce lignum \\
\hline $\mathbf{1 1 1}$ & Passio Domini pro Dominica Palmarum \\
\hline $\mathbf{1 3 6}$ & Passio Domini pro Feria Sexta Parasc. \\
\hline
\end{tabular}




\section{Appendix 3}

\section{List of cited plainchant sources of the Order of St. Paul the First Hermit}

\begin{tabular}{|l|l|l|}
\hline $\begin{array}{l}\text { Gradual } \\
\text { of Újhely }\end{array}$ & H-Bu A 115 & $\begin{array}{l}\text { Graduale Romanum, 1623, University Library, Manuscript } \\
\text { and Rare Books Collection, Budapest, A 115 }\end{array}$ \\
\hline $\begin{array}{l}\text { Processional } \\
\text { of Lepoglava }\end{array}$ & $\begin{array}{l}\text { HR-Zu R } \\
3612\end{array}$ & $\begin{array}{l}\text { Processionale ad usum Conventus Lepoglavensis, 1753, } \\
\text { Nacionalna i sveučilišna knjižnica, Zagreb, R 3612 }\end{array}$ \\
\hline $\begin{array}{l}\text { Antiphoner } \\
\text { of Lepoglava }\end{array}$ & $\begin{array}{l}\text { HR-Zu R } \\
3004\end{array}$ & $\begin{array}{l}\text { Antiphoner, cent. 18, Nacionalna i sveučilišna knjižnica, } \\
\text { Zagreb, R 3004 }\end{array}$ \\
\hline $\begin{array}{l}\text { Antiphoner } \\
\text { of Crikvenica }\end{array}$ & $\begin{array}{l}\text { HR-Zu R } \\
3038\end{array}$ & $\begin{array}{l}\text { Antiphonale Breviarii Romani, 1687, Nacionalna i } \\
\text { sveučilišna knjižnica, Zagreb, R 3038 }\end{array}$ \\
\hline $\begin{array}{l}\text { Antiphoner } \\
\text { of Pest }\end{array}$ & H-Bu A 125 & $\begin{array}{l}\text { Graduale juxta Ritum Romanum (...juxta tonum Fratrum } \\
\text { Eremitarum } \text { O. S. P. P. E.), University Library, Manuscript } \\
\text { and Rare Books Collection, Budapest, A 125 }\end{array}$ \\
\hline $\begin{array}{l}\text { Gradual } \\
\text { (Croat/Paul) }\end{array}$ & $\begin{array}{l}\text { HR-Zu R } \\
4175\end{array}$ & $\begin{array}{l}\text { Cantuale } \text { (Graduale) 1786, Nacionalna i sveučilišna knjižnica, } \\
\text { Zagreb, R 4175 }\end{array}$ \\
\hline $\begin{array}{l}\text { Vesperale } \\
\text { of Csáktornya }\end{array}$ & H-Bu A 116 & $\begin{array}{l}\text { Antiphonale Vesperas /continens..., 1769, University Library, } \\
\text { Manuscript and Rare Books Collection, Budapest, A 116 }\end{array}$ \\
\hline $\begin{array}{l}\text { Antiphoner } \\
\text { of Olimje }\end{array}$ & $\begin{array}{l}\text { HR-Zu MR } \\
178\end{array}$ & $\begin{array}{l}\text { Antiphoner, cent. 18, Metropolitanska knjižnica, Zagreb, MR } \\
\text { 178 }\end{array}$ \\
\hline $\begin{array}{l}\text { Antiphoner } \\
\text { PAUL-8 }\end{array}$ & HR-Zu MR 8 & $\begin{array}{l}\text { Antiphoner, saec. 15-16, Metropolitanska knjižnica, Zagreb, } \\
\text { MR 8 }\end{array}$ \\
\hline $\begin{array}{l}\text { Cantuale } \\
\text { of Częstochowa }\end{array}$ & PL-Cz I-215 & $\begin{array}{l}\text { Cantuale Paulinorum de Częstochowa, cent. 16, Biblioteka } \\
\text { Jasnogórska, I-215 }\end{array}$ \\
\hline $\begin{array}{l}\text { Kyrial } \\
\text { of Újhely }\end{array}$ & H-Bu A 127 & $\begin{array}{l}\text { Compendium Sacrorum (...S. A. Ujhely), 1763, University } \\
\text { Library, Manuscript and Rare Books Collection, Budapest, } \\
\text { A 127 }\end{array}$ \\
\hline $\begin{array}{l}\text { Antiphoner } \\
\text { of Máriavölgy }\end{array}$ & $\begin{array}{l}\text { H-Kf Ms. } \\
630\end{array}$ & $\begin{array}{l}\text { Antiphonale juxta Ritum S. Romanae Ecclesiae ad Normam } \\
\text { Concentus Ord. S. P. P. E., 1753, Cathedral Library, Kalocsa, } \\
\text { Ms. 630 }\end{array}$ \\
\hline
\end{tabular}

